\title{
Immune System Modulation of Germinal and Parenchymal Neural Progenitor Cells in Physiological and Pathological Conditions
}

\author{
Chiara Rolando, Enrica Boda and Annalisa Buffo \\ Department of Neuroscience \\ Neuroscience Institute Cavalieri Ottolenghi, NICO \\ University of Turin \\ Italy
}

\section{Introduction}

Historically, the Central Nervous System (CNS) was considered as an immune privileged site (Billingham and Boswell, 1953), being viewed as a territory physiologically out of the competence of immune cells. This notion has developed on initial studies showing that: (i) CNS unrelated antigens (i.e. foreign grafts, bacteria, viruses) evade an immune recognition when delivered to the brain parenchyma (Galea et al., 2007); (ii) no infiltrating immune cells nor antigen presenting cells (APCs, i.e. dendritic cells, DCs, see Table 1) can be detected in the CNS parenchyma in physiological conditions (Engelhardt and Ransohoff, 2005); (iii) CNS cells do not constitutively express major histocompatibility complex (MHC)I and MHCII molecules (Fabry et al., 1994); (iv) neural cells express apoptosis inductors for immune cells (Bechmann et al., 1999); (v) the CNS does not possess lymphatic vessels (Engelhardt and Ransohoff, 2005). The segregation between nervous and immune cells appeared tightly preserved by the anatomical separations offered by the Blood Brain Barrier (BBB) and the blood-cerebrospinal fluid barrier (Choi and Benveniste, 2004). Over time, on the basis of the association between immune inflammation and neurodegeneration, the concept of immune privilege further acquired the connotation of a defence mechanism against the detrimental effects of immune activation within the CNS.

However, during the last ten years evidence for an extensive and continuous bi-directional communication between the CNS and the immune system has accumulated, changing the traditional view of the CNS as an immune privileged site into an immune specialised site (Engelhardt and Ransohoff, 2005). Under physiological conditions, the CNS strictly controls circulating immune cell entry across its barriers by allowing a regulated exchange of factors between the nervous tissue and immune elements. Such exchange provides an incessant scavenging for self (host) and pathological antigens occurring in the CNS (immunosurveillance) and is at the basis of the newly recognised functions of immune cells in neural stem cell (NSC) activity, hippocampal neurogenesis, learning and stress-mediated responses (see below). In case of pathology, when the BBB is damaged or altered and immune attractive signals are released within the CNS, lymphocytes and macrophages 
penetrate into the CNS parenchyma. This invasion has now lost the former exclusively detrimental flavour in view of newly unveiled effects supportive for neuroprotection and reparative responses (Schwartz et al., 2009).

Studies on the interplay between the immune system and NSCs/progenitors in both health and disease have particularly contributed to this conceptual revolution in neuroimmunology. These studies are the actual focus of this chapter. We shall present them after having overviewed the main players and mechanisms involved in the CNS-immune system crosstalk.

\subsection{Routes and modes of immunosurveillance in the healthy CNS}

Main players in immunosurveillance are microglia cells residing within the CNS parenchyma, circulating monocytes and lymphocytes that mostly remain located at the outer anatomical borders of the CNS (Table 1, Schwartz and Shechter, 2010). These borders are defined by several structures: the outermost dural membrane, the arachnoid membrane and the innermost pial membrane. The subarachnoid space settles between the arachnoid and pial membrane and it is filled with the cerebrospinal fluid (CSF), which is continuously produced by the choroid plexus epithelium in the ventricular system. It circulates from the ventricle to the subarachnoid space and it is reabsorbed by the arachnoid villi that extend in the venous sinuses. The nervous artery supply follows the CNS surface in the subarachnoid space. As vessels enter the CNS parenchyma, they are surrounded by a perivascular space, the Virchow-Robin space, connected to the subarachnoid space. Moreover, the BBB separates the blood from the CNS parenchyma and is formed by highly specialized endothelial cells surrounded by basement membranes and astroglial end feet.

In the healthy CNS, immune reactivity is strictly controlled by limiting the presentation of neuroantigens outside the CNS and by tightly regulating the trafficking of immunocompetent cells. The BBB avoids leaking of neuroantigens into the systemic circulation, while within the nervous tissue microglia cells continuously survey the parenchyma with highly dynamic processes and protrusions that may clear accumulated metabolites and cell debris, thereby regulating microenvironmental homeostasis (Nimmerjahn et al., 2005). This microglial function is proposed to be directly influenced by $\mathrm{T}$ cell-derived soluble factors, at least at specific CNS sites (see section 2.1; Ziv et al., 2006a). T cells normally do not enter the healthy nervous tissue, but can reach the CSF together with monocytes (about 3000 leukocytes per ml can be found in the CSF of healthy individuals) from both vessels of the choroid plexi and post-capillary venules surrounded by the Virchow-Robin space. Soluble proteins and cells constitutively move from the CNS parenchyma into the CSF through the choroid plexi and ependymal cells and are transported up to peripheral lymph nodes, where they are presented to naïve CD4+ $\mathrm{T}$ lymphocytes (afferent arm of immunosurveillance) to achieve their first activation (see Table 1). In the efferent route of this loop, activated CD4+ T cells get to the CNS via the blood stream, and there, moving into the CSF, flow back to the systemic circulation (Ransohoff et al., 2003). The CSF is the site of secondary activation of CD4+ T cells that there encounter monocytes presenting neuroantigens and contribute to immunosurveillance without being encephalitogenic.

Very few if any leukocytes can directly access the healthy CNS parenchyma by crossing the BBB and the endothelial basal lamina. Of note, the few T cells entering the parenchyma have undergone the first activation with neuroantigens, while resting lymphocytes fail to penetrate 
even after stimulation with inflammatory cues (Ransohoff et al., 2003). The involvement of lymphocyte populations other than CD4+ T (CD8+ T, B cells and NKs) in CNS immunosurveillance has so far been considered poorly relevant, as they comprise neglectable fractions in the healthy CNS/CSF (Ransohoff et al., 2003). During pathology the scenario depicted so far can undergo dramatic changes that compromise the CNS specialised status. Dangerous antigens can be sensed locally within the CNS or directly drained to the periphery to stimulate further recruitment of immune cells. The accompanying massive release of cytokines and chemokines by immune and neural cells mediates the initiation of an immune reaction aimed at promoting CNS defence and restoring tissue homeostasis.

\subsection{Innate and adaptive immune responses in the diseased CNS}

To effectively exert its defensive functions, the immune system has developed two different reaction modes: a relatively fast and generic action against external agents (innate response), and a specific and targeted action that requires plasticity and memory (adaptive or acquired immunity). Innate and adaptive responses operate in strict collaboration and undergo distinct levels of activation depending on the type of pathology. The innate response is the first line of CNS defence, preceding and stimulating the adaptive reaction (Nguyen, 2002), and relies on microglia cells and on astrocytes. Both cell types constitutively express phagocytic and scavenger receptors (pattern-recognition receptors, PPRs) capable of distinguishing self (host) from non-self (i.e. pathogens, toxic agents and molecules released by damaged/dying cells). Peripheral macrophages/monocytes can also participate in this initial activation when lesions such as traumatic or vascular injury induce BBB breakdown and allow direct CNS parenchyma-blood interactions. Amongst PPRs are Toll-like receptors (TLRs, Table 1) that activate phagocytosis and, via the nuclear transcription factor NFkB pathway, promote the production of pro-inflammatory signals, including cytokines (Interleukin1 $\beta$, IL1 $\beta$; Tumor Necrosis Factor- $\alpha$, TNFa; IL6) and chemokines (Becher et al., 2000; Farina et al., 2007), modulating the nervous tissue response to damage (Buffo et al., 2010) and triggering adaptive immunity (Becher et al., 2000). Notably, several CNS intrinsic mechanisms operate to avoid uncontrolled or hyperactive innate responses: (i) neurons, endothelial and ependymal cells express neuroimmune regulatory proteins (NIRegs) to protect CNS cells from the phagocytic activity of macrophages and microglia and attenuate inflammatory cytokine secretion by lymphocytes (Griffiths et al., 2007); (ii) gliotic astrocytes limit blood leukocyte infiltration (Voskuhl et al., 2009).

Initiation of an adaptive immune response requires time after the initial appearance of pathogenic signals, and implies the participation of numerous cell types and signalling molecules. Adaptive immunity can be either cell-mediated (major effectors are T cells), or humoral (with the involvement of $B$ cells, see Table 1). Although humoral immune responses are most important for the organism's defence, their role in the regulation of neural stem cells and parenchymal progenitor activity is so far unknown. Thus, we shall leave them aside and focus on cell-mediated immune responses.

During CNS damage (e.g. traumatic and neurovascular injuries such as stroke) the integrity of the BBB is primarily disrupted, leading to increased and often deregulated communication between the CNS and the immune system, including the entry of immune cells. In other cases, however, an increased exchange of cellular elements and signals between the two systems occurs while the gross anatomy of the BBB is preserved, thereby 
implying more subtle functional alterations (Kaur and Ling, 2008). In some cases, such as the initial phase of Multiple Sclerosis (MS), deregulated autoimmune cellular elements find their way into the CNS where they trigger an acute inflammatory reaction to myelin components that can progress into a chronic phase of neurodegeneration. In general, after a CNS insult, resident microglia, astrocytes and DCs that can migrate from the perivascular space into the CNS parenchyma if the BBB is disrupted, present antigens to CD4+ and CD8+ $\mathrm{T}$ cells in association with co-stimulatory molecules. After priming with APCs, both $\mathrm{T}$ cell types become activated and proliferate: CD8+ T cells exert their cytotoxic activity inducing the apoptosis of antigen-bounded MHCI expressing cells, whereas CD4+ T cells produce pro- or anti-inflammatory cytokines, depending on their subtypes (Th1, Th2, see Table 1, Becher et al., 2000). Th1 cells release pro-inflammatory molecules that sustain and potentiate microglial activation in a feed-forward loop, and stimulate MHCII expression on astrocytes and endothelial cells (see Table 1). In turn, chemokines and cytokines from microglia and activated astrocytes such as interferon- $\gamma$ (INFY) and TNFa can both attract and activate immune cells (Carpentier et al., 2005). Conversely, Th2 cells exert anti-inflammatory effects through the production of IL4 and IL10, reducing macrophage and microglia activation (see Table 1). The balance between Th1/Th2 phenotypes is finely tuned by cytokines themselves (Goverman, 2009), and requires a tight regulation to avoid detrimental hyperinflammation: for instance, IL12 produced by activated microglia promotes Th1 type, while astrocytes are known to counteract this phenomenon (Becker et al., 2000).

A further modulatory mechanism of $\mathrm{T}$ cell activity involves a specific subclass of $\mathrm{T}$ cells, the CD4+ CD25+ Foxp3 T regulatory cells (Tregs, see Table1, Walsh and Kipnis, 2010). Tregs act by suppressing autoimmunity ( $T$ cells directed against self-antigens) and terminating immune responses. They exert their inhibitory action mostly through Transforming Growth Factor- $\beta$ (TGF $\beta$ ) signalling and IL10 production, which suppresses auto-reactive T cells (Vignali et al., 2008).

Further mechanisms participate in terminating immune reactions: (i) activated $\mathrm{T}$ cells themselves express receptors (i.e. CTLA-4) that reduce their proliferation and production of cytokines after interaction with microglia; (ii) $\mathrm{T}$ cells after cytokine exposure upregulate receptors that induce their apoptosis (i.e. CD95); (iii) IL2 potentiates CD95-mediated apoptosis. Thus, immune responses are self-limited and decline with time after antigenic stimulation, leaving functionally quiescent memory lymphocytes as indicators of previous antigen exposure (Parijis and Albas, 1998). Acute immune response and inflammation may therefore be soon resolved, and the damage circumscribed by astroglial scarring and microglia cells with poor replacement of lost cells and transected axons (Bush et al., 1999; Donnelly and Popovich, 2007). Yet, an involvement of abnormal autoimmunity or the persistence of pro-inflammatory stimuli can protract the inflammatory/immuno response into a chronic status and exacerbate the destructive effects of immune activation (McFarland and Martin, 2007).

Despite the described mechanisms of immune response have evolved primarily as a defence from infectious agents, they take place in all types of CNS injuries. In the following sections we will not deal with infectious diseases, but instead focus on traumatic, vascular, autoimmune damage and chronic neurodegeneration, where loss or malfunctioning of cellular elements is followed by activation and recruitment of NSCs and parenchymal progenitors, engaged for the most in replacing lost myelin rather then neurons, and in the production of scarring astrocytes (see below). 


\begin{tabular}{|c|c|c|c|c|}
\hline & Features & Functions & Molecular Signals & References \\
\hline Microglia & $\begin{array}{ll}- & \text { Invade the CNS } \\
\text { parenchyma during } \\
\text { late embryogenesis } \\
\text { and perinatal stage } \\
\text { - } \quad \text { Myeloid cells } \\
\text { - } & \text { APC upon } \\
\text { activation }\end{array}$ & $\begin{array}{|ll|}\text { - } & \text { Immunosurveillance } \\
\text { - } & \text { Innate immunity } \\
& \text { Cytokine secretion (IL1, } \\
\text { - } & \text { IL6, IL12, TNFa) } \\
& \text { Phagocytic and } \\
\text { cytotoxic activity } \\
\text { - } & \text { T cell stimulation and } \\
& \text { apoptosis (Fas ligand } \\
\text { mediated) } & \text { Neurogenesis control } \\
\end{array}$ & \begin{tabular}{|l|} 
Upregulation \\
MHCI and II \\
and CD40, \\
CD86 to activate \\
T cells \\
- $\quad$ TLR expression \\
Upregulation of \\
complement \\
receptor (CR1, \\
CR3, CR4) \\
\end{tabular} & $\begin{array}{l}\text { Yang et al., } \\
2010 \\
\text { Aloisi et al., } \\
2000\end{array}$ \\
\hline Astrocyte & $\begin{array}{ll}\text { - } & \text { Most abundant glial } \\
\text { cells in the CNS } \\
\text { Neuroectodermal } \\
\text { origin }\end{array}$ & $\begin{array}{ll}- & \text { Brain homeostasis } \\
\text { - } & \text { BBB formation } \\
\text { - } & \text { Scar formation } \\
& \text { APC function induced } \\
\text { - } & \text { by Th1 cytokines } \\
& \text { (TNokine production } \\
\text { - } & \text { Polarization of T cell } \\
& \text { cytokine responses } \\
\text { - } & \text { B cell survival and } \\
\text { differentiation } \\
\text { - } & \text { Microglia activation } \\
& \text { Neurogenesis }\end{array}$ & \begin{tabular}{|l} 
Upregulation \\
MHCII, TLRs \\
(TLRs1-6, \\
TLR9), ICAM1 \\
and VCAM1, \\
chemokines \\
(CCL2, CCL5) \\
Expression of \\
BAFF (B cell \\
activating \\
factor) \\
Neurotrophic \\
factor release \\
(BDNF, NGF, \\
IGF1, LIF)
\end{tabular} & $\begin{array}{l}\text { Carpentier et } \\
\text { al., } 2005 \\
\text { Farina et al., } \\
2007\end{array}$ \\
\hline CD4+ T & 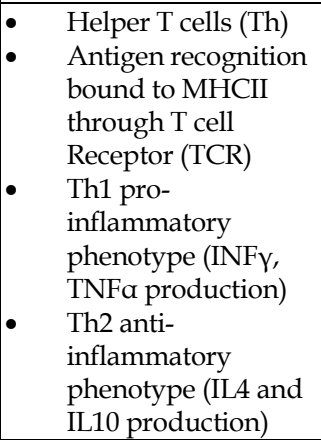 & $\begin{array}{ll} & \text { Adaptive cell-mediated } \\
\text { - } & \text { Autoimmune response } \\
\text { - } & \text { Activation of B cells }\end{array}$ & 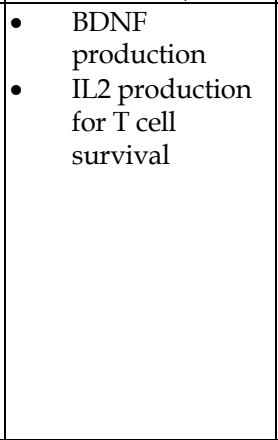 & $\begin{array}{l}\text { Goverman, } \\
2009 \\
\text { Dittel, } 2008\end{array}$ \\
\hline CD8+ T & 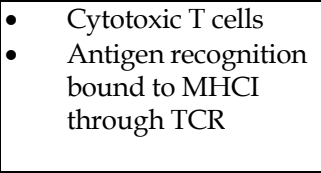 & $\begin{array}{ll}- & \text { Cytolysis (perforin } \\
\text { mediated) } \\
\text { - } & \text { CNS autoimmunity }\end{array}$ & \begin{tabular}{|l} 
Cytokine \\
production \\
(INFy and \\
TNFa, IL10, \\
IL17)
\end{tabular} & $\begin{array}{l}\text { Goverman, } \\
2009\end{array}$ \\
\hline Treg & $\begin{array}{l}\text { CD4 positive } \\
\text { Foxp3 positive } \\
\text { (forkhead box P3) } \\
\text { that controls their } \\
\text { development and } \\
\text { function and it is } \\
\text { induced by TGF } \beta \\
\text { CD25 expression } \\
\text { (IL2R) }\end{array}$ & \begin{tabular}{|l|} 
Avoidance of \\
autoimmune disease \\
and tumoral \\
autoimmunity \\
(peripheral tolerance) \\
Suppression by cytokine \\
inhibition, cytolysis, by \\
metabolic disruption, by \\
targeting DCs
\end{tabular} &  & $\begin{array}{l}\text { Vignali et al., } \\
\text { 2008; } \\
\text { Walsh and } \\
\text { Kipnis, 2010 }\end{array}$ \\
\hline
\end{tabular}




\begin{tabular}{|c|c|c|c|c|}
\hline & Features & Functions & Molecular Signals & References \\
\hline & & $\begin{array}{l}\text { - Control CD8+ T cell } \\
\text { invasion }\end{array}$ & & \\
\hline Th17 & $\begin{array}{ll}\text { - } & \text { Pro-inflammatory } \\
\text { lineage } \\
\text { Autoimmune } \\
\text { disease }\end{array}$ & 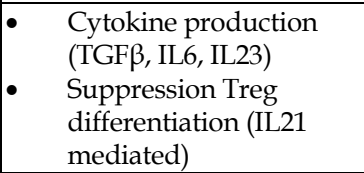 & $\begin{array}{l}\text { Activation of } \\
\text { the STAT3 } \\
\text { pathway } \\
\text { Activation of } \\
\text { RORa/ROR } \gamma\end{array}$ & $\begin{array}{l}\text { Fabry et al., } \\
2008\end{array}$ \\
\hline B cells & $\begin{array}{l}\text { - } \quad \begin{array}{l}\text { Rarely detected in } \\
\text { the healthy CSF }\end{array} \\
\text { Four different } \\
\text { developmental } \\
\text { states (mature B } \\
\text { cells, memory B } \\
\text { cells, plasmablast, } \\
\text { plasma cells) }\end{array}$ & $\begin{array}{ll}\text { - } & \text { Humoral immune } \\
\text { - } & \text { Tesponse } \\
\text { - } & \text { Ig prodl activation } \\
\text { - } & \text { APCs } \\
\text { - } & \text { Ig CNS autoantigen } \\
\text { production that induce } \\
\text { complement activation, } \\
\text { MBP proteolysis, } \\
\text { macrophages } \\
\text { stimulation }\end{array}$ & 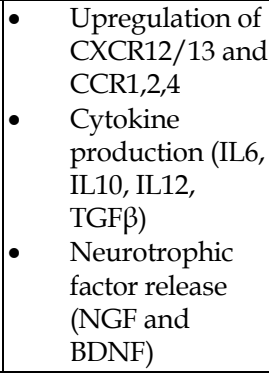 & $\begin{array}{l}\text { Meinl et al., } \\
2006\end{array}$ \\
\hline DCs & $\begin{array}{l}\text { - } \quad \text { APCs } \\
\text { Lymphoid and } \\
\text { myeloid origin } \\
\text { Localized in the } \\
\text { meninges and } \\
\text { chroid plexi in the } \\
\text { healthy brain } \\
\text { During } \\
\text { inflammation, } \\
\text { autoimmune } \\
\text { diseases and } \\
\text { neurodegeneration } \\
\text { they reach the CNS } \\
\text { parenchyma }\end{array}$ & $\begin{array}{ll} & \text { Immunosurveillance } \\
\text { T cell stimulation, } \\
\text { tolerance induction, T } \\
\text { cell polarization, } \\
\text { phagocytosis, cytokine } \\
\text { secretion (IL1b, IL6, } \\
\text { IL10, IL12, TNFa, INFY) }\end{array}$ & \begin{tabular}{|l} 
MHC class II, \\
costimulatory \\
proteins (CD40, \\
CD80, CD86), \\
chemokine \\
receptor (CCR7)
\end{tabular} & $\begin{array}{l}\text { McMahon et } \\
\text { al., } 2006\end{array}$ \\
\hline $\begin{array}{l}\text { Toll like } \\
\text { Receptors } \\
\text { (TLR) }\end{array}$ & \begin{tabular}{|l} 
- \\
Expressed on APCs \\
including microglia \\
and DCs \\
Surface recognition \\
of PAMPs \\
Expression on \\
resting and activated \\
microglia and \\
astrocytes (TLR3 on \\
astrocytes, TLR2 and \\
TLR4 on microglia) \\
Extracellular portion \\
with multiple \\
leucine-rich repeats
\end{tabular} & $\begin{array}{l}\text { Recognition of } \\
\text { exogenous components } \\
\text { of the bacterial } \\
\text { membrane and flagella, } \\
\text { bacterial DNA and viral } \\
\text { dsRNA } \\
\text { Neurogenesis }\end{array}$ & $\begin{array}{l}\text { - } \\
\text { - } \\
\text { Cytokine and } \\
\text { chemokine } \\
\text { production }\end{array}$ & $\begin{array}{l}\text { Farina et al., } \\
2007 \\
\text { Rolls et al., } \\
2007\end{array}$ \\
\hline
\end{tabular}

Table 1. Immunoplayers.

Main cellular types and molecular signals that regulate the interplay between the immune system and the CNS. This process involves the participation of CNS resident cells (microglia and astrocytes), immune system cells and numerous molecular signals. 


\section{Immune-based regulation of adult Neural Stem Cell activities and neurogenesis}

In the adult brain NSCs displaying astrocytic features reside in two anatomically defined germinal niches, namely the subventricular zone (SVZ) of the lateral wall of the lateral ventricles and the subgranular zone of the hippocampus (SGZ). Adult NSCs of the SVZ (also termed Type-B cells) retain the capability to asymmetrically divide, giving rise to actively proliferating intermediate neural progenitors defined as transit amplifying cells or Type-C cells. These latter cells symmetrically divide to produce neuroblasts (Type-A cells) that migrate through the Rostral Migratory Stream (RMS) into the olfactory bulb, where they eventually differentiate in interneurons. In vivo type-B cells can also generate oligodendroglial cells of the corpus callosum and fimbria fornix, although to a lesser extent compared to neurons (Kriegstein and Alvarez-Buylla, 2009). NSCs residing within the hippocampal SGZ divide asymmetrically to give rise to neuroblasts that locally differentiate into mature granular neurons (Kriegstein and Alvarez-Buylla, 2009). Numerous studies indicate that continuous neurogenesis in the olfactory bulb and hippocampus is instrumental for memory acquisition, learning and mood regulation (Zhao et al., 2008), while both physiological (i.e. life experiences, such as learning, physical activity, environmental or olfactory enrichment, stress) and pathological (i.e. brain insults or pathologies, local or systemic inflammation) stimuli affect NSCs and their derivatives.

Surprisingly, a number of recent studies have provided evidence that local and systemic immune-mediated mechanisms, including both innate and adaptive factors, exert a key role in modulating neuro/oligodendrogenic events within the germinal niches in healthy and pathological conditions. Such immune-based regulation takes place at many levels, including (i) proliferation of NSCs and intermediate progenitors; (ii) neuronal vs. glial specification of NSC-derivatives; (iii) migratory ability of the new-born elements; and (iv) their survival, maturation and integration in the adult brain parenchyma. Since the identity of immune system players and the level of their recruitment/activation/production are dramatically different in distinct brain conditions (i.e. healthy vs. acutely injured vs. chronically diseased), immune modulation displays complex and context-dependent effects on the functioning and survival of NSCs and their derivatives (see below). For the sake of simplicity and brevity, in the following text we will refer to germinal functions as "neuro/oligodendrogenesis" or "neuro/oligodendrogenic activity", while the specific effects of immune elements on the diverse germinal components and activities will be dissected in Table 2 (see also Figure 1).

\subsection{Immune regulation of adult germinal niche functioning under physiological conditions}

Among all immune elements, microglial cells are reportedly crucial modulators of neurogenic niche activities in both the healthy and injured adult CNS. They populate both adult SVZ and SGZ, where they localize in close proximity to NSCs. Interestingly, germinal microglia displays phenotypes and behaviours (i.e. higher levels of activation, proliferation and phagocytic activity; Goings et al., 2006; Ziv et al., 2006a; Sierra et al., 2010) distinct from both their resting counterparts in the non-neurogenic CNS parenchyma, and fully activated and phagocytic microglia detected upon injury or in inflammatory conditions. In vitro experiments suggest that such basal germinal activated (BGA) phenotype is maintained 
through interactions with components of the niche environment, including matrix molecules (e.g. Tenascin-R; Liao et al., 2008), low levels of inflammatory molecules (e.g. IL4 and IFN $\gamma$ ), and elements of adaptive immunity (see below; Ziv et al., 2006a). Notably, various studies report a positive correlation between the persistence of the BGA microglial state and basal levels of neurogenesis and oligodendrogenesis both in vivo and in vitro (see also Table 2), with blockade of any microglial activation by minocycline resulting in decreased numbers of newborn neurons (Carpentier and Palmer, 2009 and references therein). In vitro studies suggest that, although microglial cells are abundantly distributed within the germinal niches in the adult CNS, direct contacts between microglia and NSCs/precursors/ neuroblasts may not be required for facilitating neurogenesis (Aarum et al., 2003; Walton et al., 2006). Notably, microglia cells residing within the germinal niches constitutively secrete a plethora of soluble mediators, including growth factors (e.g. Brain Derived Neurotrophic Factor BDNF and Insulin-like Growth Factor IGF1; Liao et al., 2008; Ziv et al., 2006a) and low levels of inflammatory molecules (e.g. TGF $\beta$, TNF $\alpha$, IL1 $\beta$; Battista et al., 2006; Liao et al., 2008; Carpentier and Palmer, 2009; Yirmiya and Goshen, 2011). Both categories of mediators are importantly implicated in neurogenesis, as attested by the negative outcomes on constitutive NSC functioning of genetically- or pharmacologically-driven ablation of growth factor- or inflammatory cytokine-mediated signalling pathways (see also Table 2; Ziv et al., 2006a; Butovsky et al., 2006; Carpentier and Palmer, 2009 and references therein). Moreover, microglia-derived inflammatory molecules can directly influence basal NSC/progenitor functions, as these cells express a set of cytokine receptors, including those for IFN $\gamma$ (Li et al., 2010), TNF $\alpha$ (Carpentier and Palmer, 2009), IL1 $\beta$ (Yirmiya and Goshen, 2011) and IL6 (Monje et al., 2003). Moreover, pioneer studies reported that adult NSCs basally display a set of features typical of immune cells, including the expression of MHC-related molecules, TLRs and complement receptors, whose activation may allow NSCs themselves to (i) act as antigenpresenting cells; (ii) directly sense alterations in tissue integrity and immune system activity upon injury; and (iii) plastically modulate their own neuro/oligodendrogenic activity in response to environmental alterations (see Table 2; Popa et al., 2011; Rolls et al., 2007; Moriyama et al., 2011; Rahpeymai et al., 2006).

Further novelty in the field has been provided by the unexpected discovery that, in addition to resident microglia and derived soluble factors, $\mathrm{T}$ cells contribute to maintain the neurogenic homeostasis in the adult CNS. By using nude or SCID (severe combined immune deficiency) mice, lacking respectively either only mature $\mathrm{T}$ cells or both $\mathrm{T}$ and $\mathrm{B}$ cell populations, Michal Schwartz and colleagues in 2006 demonstrated that $T$ cell deficiency is correlated with impaired NSC/progenitor proliferation and neuronal differentiation of new born derivatives in both SGZ and SVZ, accompanied by a defective spatial learning ability (Ziv et al., 2006a). Such effect on SGZ progenitor cells is specifically exerted by $\mathrm{T}$ helper lymphocytes, as repopulation with CD4+, but not CD8+ or B cells, rescues defective neurogenesis (Wolf et al., 2009). Notably, antigenic specificity to CNS autoantigens and the consequent lymphocyte homing to the CNS appear required for the expression of these $\mathrm{T}$ cell supportive effects on neurogenesis. Consistently, transgenic (tg) mice in which the majority of the $\mathrm{T}$ cell population is directed to an irrelevant antigen (i.e. ovalbumin) show impaired hippocampal neurogenesis, while, conversely, tg mice in which the majority of the $\mathrm{T}$ cells is directed to a CNS-specific antigen, such as certain peptides of the myelin basic protein (MBP), display increased hippocampal neurogenesis (Ziv et al., 2006a). Interestingly, data collected so far allow to 
propose a model in which the homeostatic role of $\mathrm{T}$ cells on germinal niche functions includes both a direct action on NSCs and their derivatives via release of BDNF, and an indirect effect mediated by modulation of the microglial BGA state and increased BDNF production induced in surrounding neurons (Ziv et al., 2006a; Hohlfeld et al., 2006). In line with this scenario, minocycline treatment results in a reduced hippocampal neurogenesis even in tg mice where $\mathrm{T}$ cells are directed to MBP antigens, while BDNF levels are reduced in immune deficient mice and elevated in $\mathrm{tg}$ mice enriched with $\mathrm{T}$ cells directed to MBP antigens (Ziv et al., 2006a; Wolf et al., 2009).

The participation of immune cells in the regulation of hippocampal NSCs/progenitors is further supported by experiments showing that while wild type mice respond to enriched housing conditions (including social, sensory and motor stimulation) by increased neurogenesis, SCID animals do not show any change in NSC activity (Ziv et al., 2006a). Notably, in the same experimental condition it has been reported the appearance of $\mathrm{T}$ cells in the hippocampal hilus and an increased number of SGZ microglial cells upregulating MHCII molecules and IGF1 (Ziv et al., 2006a). Since this microglia phenotype is typically promoted by Th2-derived IL4 (Butovsky et al., 2005), it can be speculated that these changes are stimulated by defined $\mathrm{T}$ cell activities occurring as a consequence of the organismenvironment interactions. In addition, based on the capability of microglia stimulated by either IL4 or low levels of INFr (which is known to be produced by T cells) to promote neurogenesis and oligodendrogenesis in hippocampal progenitor cell/microglia co-cultures, (Butovsky et al., 2006), one may claim that the observed microglia changes contribute to the occurring increased neurogenesis. Stress and elevated levels of circulating glucocorticoid hormones can also affect the BGA microglial state (Song and Wang, 2011). Accordingly, the surgical removal of the adrenal gland and the consequent suppression of glucocorticoid production result in a moderately higher activation of microglial cells, whose density increase again correlates with a higher number of dividing cells and of newly generated neurons in the SGZ. Such microglial activation is accompanied by the upregulation of inflammatory cytokines, such as TGF $\beta$ (Battista et al., 2006). Taken together, these data indicate that $\mathrm{T}$ lymphocytes and microglia cells take part in the homeostatic regulation of adult neurogenesis, comprising the mediation of part of the pro-and anti-neurogenic effects of experience/emotional stimuli.

Another study confirmed the contribution of immune cells to the plastic regulation of adult neurogenesis. Wolf and colleagues in 2009 showed that when the effect of voluntary wheel running on neurogenesis is assessed in CD4 knock-out mice or in mice treated with antiCD4 neutralizing antibodies, both wild type and CD4-depleted/deficient mice respond by increased hippocampal proliferation (although starting from different basal levels), while such expected effect is absent only in mice devoid of functional T, B and NK cells. This latter finding suggests that while CD4+ T cells are the major player in controlling constitutive neurogenesis, the entire pool of adaptive immune cells may contribute to induce a response to neurogenic stimuli. Only one study so far excluded a role for $\mathrm{T}$ cells and microglia activation in activity-induced increase of adult hippocampal neurogenesis (Olah et al., 2009). Whether differences in experimental paradigms applied (voluntary physical activity vs. enriched environment) or in animal models used (mice vs. rats) account for such different results remains to be assessed. 
To sum up, data collected so far provide evidence that in non-pathological conditions both resident microglia and $\mathrm{T}$ cells have a prominent role in maintaining and plastically modulating the basal levels of neurogenesis within the adult CNS (see Figure 1). Microglia residing within the neurogenic niches displays a germinal-specific basally activated phenotype, characterized by the expression of defined pro-neurogenic inflammatory mediators (e.g. TGF $\beta, \mathrm{TNF} \alpha, \mathrm{IL} 1 \beta$ ) and growth factors (e.g. BDNF and IGF1). The maintenance of such BGA microglial phenotype depends on the interaction with local elements and with CNS-directed T cells, and positively correlates with the neurogenic activity of adult germinal niches.

\subsection{Immune system regulation of germinal niche functioning after injury}

The discovery of the retention of NSCs within the mature CNS has inspired two decades of intense investigations aimed at assessing whether such endogenous source of new neurons and oligodendrocytes could be exploited for the repopulation of lost neuronal populations and the restoration of damaged myelin sheaths. However, it is now well established that adult germinal niche activity has a very limited ability to mediate a longlasting cell replacement and to support a complete repair of the injured CNS cytoarchitecture and functions. Many studies have shown that early after acute insults (e.g. stroke, trauma, single epileptic attacks, acute phase of relapsing-remitting experimental autoimmune encephalomyelitis EAE) endogenous neurogenesis and oligodendrogenesis are stimulated. However, in most cases reactive neurogenesis is eventually abortive, since the majority of the newly generated neurons are not recruited to the lesion site but remain within the germinal areas, nor are integrated into the parenchyma, and ultimately undergo cell death (Carpentier and Palmer, 2009). Moreover, in chronic pathologies (e.g. neurodegenerative diseases, recurrent seizures, chronic progressive EAE) and stress conditions (e.g. mouse isolation), neurogenesis and oligodendrogenesis appear impaired (Carpentier and Palmer, 2009; Pluchino et al., 2008; Rasmussen et al., 2011). Studies using ablation of single immune cell populations or molecular pathways have revealed that upon injury immune system elements exert a dual role, contributing to both the early neuro/oligodendrogenic reaction and the subsequent establishment of a milieu non-permissive for NSC activities. Major players in such regulation are again microglia and $\mathrm{T}$ cells (see below).

Early after acute damage, cell debris, nucleotides released from dying cells and reactive glial cells, and extracellular matrix protein fragments serve as ligands for the TLRs expressed by microglia residing within the germinal niches, and trigger its full activation, with subsequent release of high levels of pro-inflammatory cytokines (i.e. TNF $\alpha$, INF $\gamma$, IL6 and IL1 $\beta$ ) and growth factors (e.g. IGF1; Ekdahl, 2009 and references therein; Deierborg et al., 2010). Various studies reported that such early microglial activation is per se needed to induce the post-injury increase of neurogenesis. In fact, minocycline inhibition of activated microglial cells exposed to injury (i.e. stroke) abolishes the increase in NSC proliferation both in vivo and in vitro (Kim et al., 2010; Deierborg et al., 2010). Consistently, genetically- or pharmacologically-driven ablation of IL1 $\beta$ - or TNF $\alpha$ mediated signalling pathways negatively affects neurogenesis after seizures and stroke (Spulber et al., 2008; Carpentier and Palmer, 2009 and references therein), indicating that, 
in addition to growth factors, these microglial-derived mediators contribute to post-injury reactive neurogenesis. Notably, similar to the healthy conditions, defined subpopulations of $\mathrm{T}$ cells contribute to modulate germinal niche functioning at early stages after injury. Removal of the whole CD4+ T cell population results in increased precursor/neuroblast generation few days after stroke, while depletion of the only Treg lymphocytes suppresses neurogenesis and reduces functional recovery (Saino et al., 2010). In contrast, promotion of Treg homing to the ischemic brain enhances NSC and neuroblast survival (Ishibashi et al., 2009). At variance with non-pathological conditions, post-injury $\mathrm{T}$ cell effects appear to modulate pro-inflammatory cytokine secretion by activated endothelial cells rather than being mediated by microglial functions (Saino et al., 2010; Ishibashi et al., 2009).

When persistent and uncontrolled microglial activation occurs, the same molecular players appear to switch their acute stimulating function into detrimental effect on germinal niche activity. For instance, when minocycline is administered in the chronic phase of CNS injuries or diseases, such treatment results in increased generation of neurons and oligodendrocytes (Carpentier and Palmer, 2009; Yirmiya and Goshen, 2011 and references therein; Rasmussen et al., 2011). Whether such phenomenon is due to a beneficial-todetrimental switch in the microglial phenotype is still highly debated. It remains also unresolved whether changes in the intrinsic responsiveness to immuno/inflammatory mediators of NSCs and their derivatives may account for these harmful effects. Although data are not completely consistent (Ekdahl, 2009), transcriptional profiling of isolated SVZ microglia cells reveals that microglia exhibits disease phase-specific gene expression signatures (Starossom et al., 2011). Moreover, in vitro evidence suggests that while earlyactivated microglia displays pro-neurogenic features, it acquires a non-supportive phenotype at delayed time point after injury (Deierborg et al., 2010). Moreover, inflammatory cytokines can act through different receptors, thereby triggering distinct effects. This is the case of TNF $\alpha$ that can activate both the TNF $\alpha$ receptor 1 (TNFR1), mediating cytotoxic functions on NSCs and neuroblasts, and the TNFR2, activating proneurogenic pathways (Carpentier and Palmer, 2009). These data suggest that upon chronic damage both microglia and NSC can contribute to reduced neuro/oligodendrogenesis, by acquiring phenotypes non-supportive for germinal niche functioning and newborn cell survival.

In summary, early microglia activation is required to induce post-injury increase in NSC proliferation and neurogenesis. However, when microglial activation and inflammatory molecule secretion persist for long time, as in chronically injured CNS, adult neurogenesis and oligodendrogenesis are suppressed. At variance with what reported in physiological conditions, at early stages after injury CD4+ $\mathrm{T}$ cell activity negatively affects precursor/neuroblast generation through microglia-indipendent mechanisms. However, under the same conditions, the Treg subpopulation appear to exert beneficial effects on neurogenesis and functional recovery (see Figure 1).

Although still controversial, these data support the idea that anti-inflammatory treatments should be finely and temporarily calibrated in order to be beneficial for neuro/oligodendrogenesis and promote CNS regeneration following injury. 

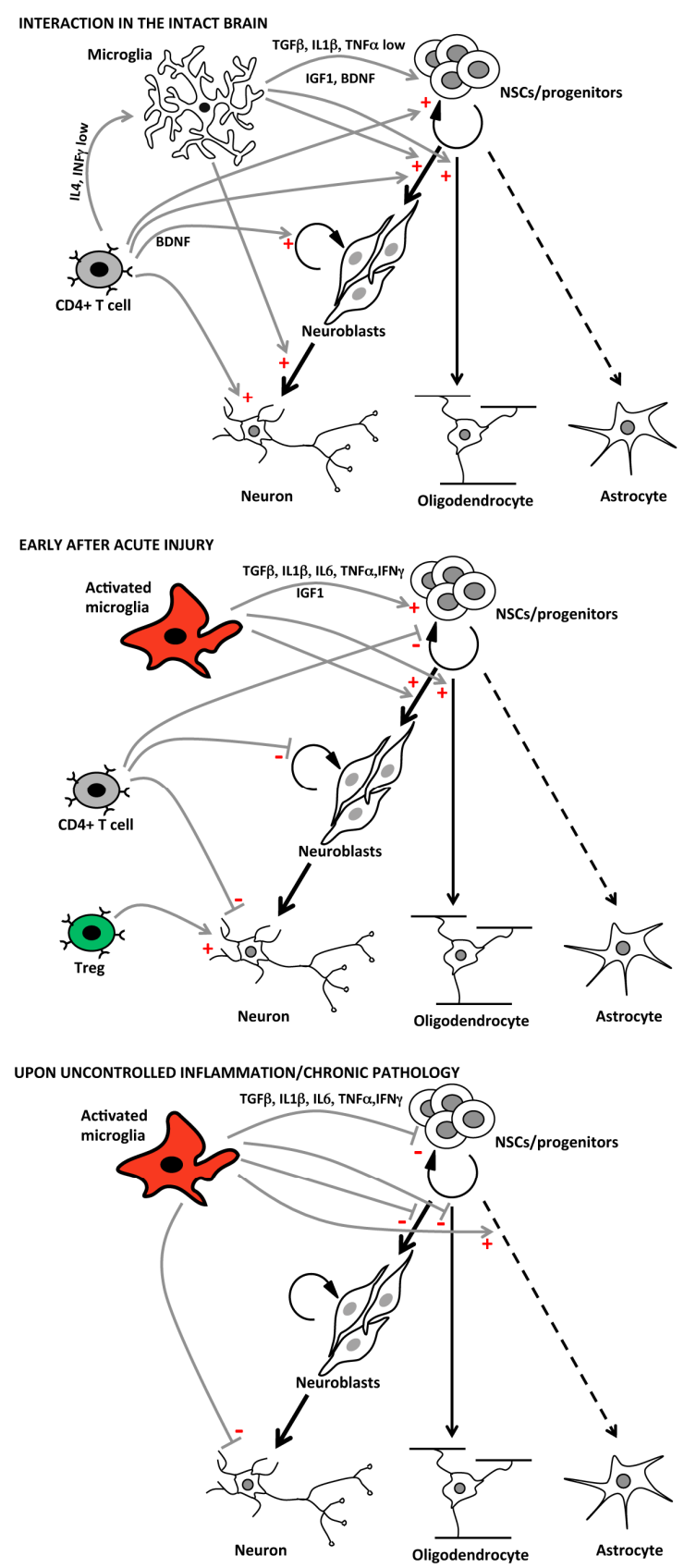

Fig. 1. Immune-based regulation of adult germinal niche activities in intact and pathological conditions. Curved arrows indicate proliferation; straight arrows indicate differentiation along cell lineages. 
In the adult brain NSCs residing in the SVZ and SGZ asymmetrically divide and give rise to actively proliferating neuroblasts that eventually differentiate in mature neurons into the olfactory bulb or in the dentate gyrus. Within the adult germinal niches, oligodendrocytes and astrocytes are also produced, though to a much lesser extent. Depending on their state of activation, immune system elements can positively $(+)$ or negatively $(-)$ affect the generation of new neurons or glial cells within the mature CNS. Immune-mediated mechanisms include microglia- and T cell-derived soluble factors, and influence (i) NSC and neuroblast proliferation, (ii) neuronal vs. glial specification, (iii) survival and maturation of the newborn elements, thereby exerting an important role in modulating the germinal niche activities in both healthy and pathological conditions.

\begin{tabular}{|c|c|c|c|c|c|}
\hline Immunoplayer & Proliferation & Specification & Survival & $\begin{array}{c}\text { Neuroblast } \\
\text { differentiation }\end{array}$ & $\begin{array}{l}\text { Oligodendro } \\
\text { genesis }\end{array}$ \\
\hline \multicolumn{6}{|l|}{$\begin{array}{l}\text { Immune } \\
\text { cells }\end{array}$} \\
\hline \multicolumn{6}{|l|}{ Microglia } \\
\hline $\begin{array}{l}\text { in physiological } \\
\text { conditions }\end{array}$ & $\begin{array}{c}+ \\
\text { (NSCs/ } \\
\text { precursors) }\end{array}$ & n.r. & n.r. & + & + \\
\hline $\begin{array}{l}\text { early after acute } \\
\text { injury }\end{array}$ & $\begin{array}{c}+ \\
\text { (NSCs/ } \\
\text { precursors) }\end{array}$ & $\begin{array}{l}\text { + neurogenesis } \\
+ \text { oligodendro- } \\
\text { genesis }\end{array}$ & n.r. & n.r. & + \\
\hline $\begin{array}{l}\text { in chronic } \\
\text { pathology/ } \\
\text { uncontrolled } \\
\text { immuno- } \\
\text { activation }\end{array}$ & $\begin{array}{c}- \\
\text { (NSCs/ } \\
\text { precursors) }\end{array}$ & - neurogenesis & $\begin{array}{c}- \\
\text { (neurobl.) }\end{array}$ & n.r. & - \\
\hline \multicolumn{6}{|l|}{ CD4+ T cells } \\
\hline $\begin{array}{l}\text { in physiological } \\
\text { conditions }\end{array}$ & $\begin{array}{c}+ \\
\text { (NSCs/ } \\
\text { precursors/ } \\
\text { neurobl.) }\end{array}$ & + neurogenesis & $\begin{array}{c}+ \\
\text { (neurobl.) }\end{array}$ & + & n.r. \\
\hline early after injury & $\begin{array}{c}- \\
\text { (NSCs/ } \\
\text { precursors/ } \\
\text { neurobl.) } \\
\end{array}$ & n.r. & $\begin{array}{c}- \\
\text { (precursor/ } \\
\text { neurobl.) }\end{array}$ & n.r. & n.r. \\
\hline T regs & n.r. & n.r. & $\begin{array}{c}+ \\
\text { (neurobl.) } \\
\end{array}$ & n.r. & n.r. \\
\hline \multicolumn{6}{|l|}{$\begin{array}{l}\begin{array}{l}\text { Inflammatory } \\
\text { cytokines }\end{array} \\
\end{array}$} \\
\hline TGF $\beta$ & n.r. & + neurogenesis & n.r. & + & \\
\hline IL4 & n.r. & n.r. & n.r. & + & + \\
\hline IL1 $\beta$ & $\begin{array}{c}- \\
\text { (in vitro; NSCs/ } \\
\text { precursors); } \\
+ \\
\text { (in vivo; NSCs/ } \\
\text { precursors) } \\
\end{array}$ & n.r. & n.r. & n.r. & n.r. \\
\hline IL6 & $\begin{array}{c}- \\
\text { (NSCs/ } \\
\text { precursors/ } \\
\text { neurobl.) }\end{array}$ & $\begin{array}{c}+ \text { astroglio- } \\
\text { genesis } \\
\text { - neurogenesis }\end{array}$ & - & n.r. & n.r. \\
\hline
\end{tabular}




\begin{tabular}{|c|c|c|c|c|c|}
\hline Immunoplayer & Proliferation & Specification & Survival & $\begin{array}{c}\text { Neuroblast } \\
\text { differentiation }\end{array}$ & $\begin{array}{c}\text { Oligodendro } \\
\text { genesis }\end{array}$ \\
\hline TNF $\alpha$ & $\begin{array}{c}- \\
\text { (>200ng/ml; } \\
\text { precursors); } \\
+ \\
(1 \mathrm{ng} / \mathrm{ml} ; \\
\mathrm{NSCs} / \\
\text { precursors/ } \\
\text { neurobl.) }\end{array}$ & n.r. & $\begin{array}{c}- \\
(10-100 \\
\text { ng/ml; } \\
\text { NSC/ } \\
\text { precursors); } \\
+ \\
(1 \mathrm{ng} / \mathrm{ml} ; \\
\text { NSCs/ } \\
\text { precursors/ } \\
\text { neurobl.) }\end{array}$ & $\begin{array}{c}+ \\
(1 \mathrm{ng} / \mathrm{ml}) ; \\
\text { No effect } \\
(10 \mathrm{ng} / \mathrm{ml})\end{array}$ & n.r. \\
\hline IFN $\gamma$ & $\begin{array}{c}- \\
\text { (NSCs/ } \\
\text { precursors) }\end{array}$ & $\begin{array}{l}\text { + neurogenesis } \\
\text { - oligodendro- } \\
\text { genesis } \\
\text { (in vivo); } \\
\text { - astroglio- } \\
\text { genesis } \\
\text { (in vitro); } \\
\text { - neurogenesis } \\
\text { - oligodendro- } \\
\text { genesis } \\
\text { + astroglio- } \\
\text { genesis } \\
\text { (neurosphere } \\
\text { assay) }\end{array}$ & $\begin{array}{c}- \\
\text { (neurobl.) }\end{array}$ & $\begin{array}{c}+ \\
(20 \mathrm{ng} / \mathrm{ml})\end{array}$ & - \\
\hline \multicolumn{6}{|l|}{$\begin{array}{l}\text { Receptors on } \\
\text { NSCs and } \\
\text { derivatives } \\
\end{array}$} \\
\hline TLR2 & n.r. & + neurogenesis & n.r. & + & n.r. \\
\hline TLR4 & $\begin{array}{c}- \\
(\mathrm{NSCs})\end{array}$ & n.r. & $\begin{array}{c}+ \\
+ \\
\text { (neurobl.) }\end{array}$ & + & n.r. \\
\hline $\begin{array}{l}\text { CR2 } \\
\text { complement } \\
\text { receptor }\end{array}$ & $\begin{array}{c}- \\
\text { (NSCs/ } \\
\text { precursors/ } \\
\text { neurobl.) }\end{array}$ & n.r. & n.r. & n.r. & n.r. \\
\hline \begin{tabular}{|l|} 
C3aR \\
complement \\
receptor
\end{tabular} & n.r. & n.r. & n.r. & + & n.r. \\
\hline $\begin{array}{l}\text { RAE-1 (MHCI - } \\
\text { related) }\end{array}$ & $\begin{array}{c}+ \\
\text { (NSCs/ } \\
\text { precursors) }\end{array}$ & n.r. & n.r. & n.r. & n.r. \\
\hline
\end{tabular}

Table 2. Major immune factors regulating the adult germinal niche activity.

Data were obtained from studies in which genetically- or pharmacologically-driven ablation of single cell populations or molecular pathways allows to unveil a causal relationship between the activity of a defined cell type or molecule and a specific effect on NSC or derivatives. References can be found in the text. Note that the effects of inflammatory cytokines are often context- or dose-dependent. Abbreviations: NSCs, Neural Stem Cells; neurobl., neuroblasts; +, increased; -, decreased; n.r., not reported. 


\section{Immune system regulation of parenchymal neural progenitors}

Studies over the last decades have revealed that glia cells residing in the nervous parenchyma outside the neurogenic areas can display progenitor functions (Boda and Buffo, 2010), in addition to absolving supportive roles for neurons and contributing to information processing (Kettenmann and Verkhratsky, 2008; Bakiri et al., 2009). Typically, cells expressing the proteoglycan NG2 comprise the vast majority of cycling elements outside the germinal areas (Horner et al., 2000; Dawson et al., 2003) and respond to a variety of lesion conditions by an increased cytogenic activity and hypertrophy (Keirstead et al., 1998; Reynolds et al., 2002; Hampton et al., 2004). Conversely, mature parenchymal astrocytes remain quiescent in the healthy CNS, but can re-enter the cell cycle and assume features of progenitor cells upon injury (Buffo et al., 2008, 2010). Numerous approaches including proliferation studies, expression analysis, grafting experiments and Cre-lox based fatemapping investigations (revised in Trotter et al., 2010; Richardson et al., 2011) have consolidated the view of NG2 positive cells as endogenous reservoir of mature and myelinating oligodendrocytes during development, adulthood and in most pathological conditions. Therefore, these cells are generally termed oligodendrocyte precursor cells (OPCs), despite the names 'polydendrocytes' or 'synanthiocytes' have been recently adopted in view of their morphology and contiguity to neurons. A controversial issue, dawned by seminal experiments showing that OPCs in vitro can revert to a stem cell-like state and differentiate along all the three neural lineages (Kondo and Raff, 2000), is whether in vivo these cells can undergo low levels of neurogenesis and generate glial cells other than oligodendrocytes at specific CNS sites or in specific conditions. Data on this issue are conflicting, although the prevailing view agrees that some astrogliogenesis (and generation of Schwann cells in the spinal cord) can occur in defined injury conditions and developmental ages (embryonic astrogliogenesis). Production of new neurons has also been reported, but remains to be further confirmed (see Boda and Buffo, 2010; Richardson et al., 2011; Fröhlich et al., 2011 for review). Recent studies on CNS lesions have also attributed precursor properties to reactive astrocytes and spinal cord ependymal cells. During anisomorphic gliosis, parenchymal astrocytes dedifferentiate and acquire progenitor features, which are not expressed in vivo, likely inhibited by a plethora of injury-evoked restrictive signals such as inflammatory molecules, but can be disclosed ex vivo (Buffo et al., 2008; 2010). Spinal cord ependymal cells appear instead able to undergo astrogliogenesis and oligodendrogenesis upon injury directly in vivo (Barnabè-Heider et al., 2010).

\subsection{Protective and destructive effects of immune activation in the nervous tissue}

As presented above (see also Table 2), poor survival of progenitor cells as well as restriction of their differentiation potentials to astrogliogenesis, blockade of maturational programs and induction of cell death have been long ascribed to immuno-mediated inflammatory signals released at sites of lesions. This purely negative view of immunity and inflammation has also extended to parenchymal progenitor functioning, based on the established detrimental inflammatory burden of immune (e.g. MS), traumatic, neurovascular and neurodegenerative (Alzheimer's Disease, Parkinson disease, Amyotrophic Lateral Sclerosis) pathologies. However, recent studies have highlighted a positive contribution of immunity to repair of neural damage. Thus, while nothing is known on whether and how both local microglia and peripheral immune cells physiologically modulate the proliferation and 
differentiation rates of OPCs and/or affect the progenitor potentials of other glial cells, it is increasingly clear that the concept of immune activation as purely harmful to CNS repair is too simplistic. Accordingly, well-defined features, levels and timing of immune activity appear to promote neuroprotection and post-injury plasticity in the forms of axon regrowth, replacement of degenerated cells and functional recovery.

This emerging view suggests that supportive functions for tissue repair and functional recovery can be exerted by defined populations or functional states of macrophages/microglia and T cells. For instance, infiltrating blood-derived macrophages have been shown to promote recovery at sub-acute stages in rodents with spinal cord injury (Rapalino et al., 1998; Shechter et al., 2009). This action appears related to the production of immunomodulatory (anti-inflammatory IL10) and neurotrophic molecules (BDNF), which is triggered by exposure to self-antigens or by the actions of $\mathrm{T}$ cells responding to neuroantigens ('protective autoimmunity', Schechter et al., 2009; see also Schwartz and Yoles, 2006; Schwartz and Shechter, 2010). A similar modulatory function would be exerted by $\mathrm{T}$ cells on local microglia that, upon proper stimulation, can become beneficial to the nervous tissue (Butovsky et al., 2005, 2006; Shaked et al., 2005). According to this view, autoimmune $\mathrm{T}$ cells sensibilised against CNS antigens (and in particular myelin components) (Moalem et al., 1999; Hauben et al., 2000; Kipnis et al., 2002; Fisher et al., 2001; Beers et al., 2008) have been proposed to play a crucial role in the recovery from acute CNS insults. These cells would enhance cellular and molecular mechanisms responsible of cleaning up the injured area and creating a milieu favourable to tissue remodelling and function restoration. Yet, in autoimmune neuropathologies such as EAE Tregs have been primarily implicated in neuroprotection and inflammation control (Liu et al., 2006; Huang et al., 2009; Reddy et al., 2004), where they would partly contribute to limiting the overactivation of cytotoxic autoimmune cells. A similar function for Tregs in nonautoimmune CNS damage has been confirmed by a further study on a stroke model (Liesz et al., 2009). The important novelty of these findings resides on the identification of physiological reparative mechanisms mediated by innate and adaptive immunity that, in the natural state may remain too weak or abortive to express their full neuroprotective and reparative potential, and could therefore be implemented for therapeutic purposes (Schwartz and Yoles, 2006; Walsh and Kipnis, 2011). In other words, with distinct timings and modalities, defined immune cell populations can be proposed as an endogenous therapeutic target to restrain or modulate self-checking mechanisms on the part of beneficial immunity activated spontaneously in response to CNS injury (Walsh and Kipnis, 2011). However, any immediate extension of this view to all types of CNS injury, including chronic neurodegenerative diseases, requires further confirmations and disclosure of the specific mechanisms of immune cell actions in distinct disease conditions (Walsh and Kipnis, 2011).

\subsection{Immune-mediated control of parenchymal progenitor functioning}

Whereas the above presented findings referred to nervous tissue protection and recovery from damage in general terms, in this section we will take a closer look on how and when innate and adaptive cells and inflammatory cues influence the activity and survival of OPCs and parenchymal progenitors. Oligodendrocyte produce myelin sheaths that allow fast conduction of electrical signals along axons. These cells undergo primary degeneration due to genetic causes (leukodistrophies) and are highly vulnerable to noxious signals produced 
during traumatic and ischemic events and inflammatory/autoimmune pathologies. In many instances their replacement with subsequent remyelination of temporary demyelinated axons occurs spontaneously. However, if oligodendrocyte death is particularly extended or in defined damage conditions such as traumatic compressive injuries, stroke and MS, this process remains incomplete or blocked. Neo-oligodendrogenesis and remyelination are not operated by spared mature oligodendrocytes but by OPCs. To attain remyelination, these progenitors have to become activated, undergo hyperthrophic changes, activate fast proliferation, migrate to the site of demyelination, start a complex differentiation process including the establishment of contacts with the denudated axons, expression of myelin genes, generation of the myelin membranes that wrap the axons and form the sheath. It is unquestionably true that OPCs respond to a variety of insults other than demyelination. Amongst these, compelling evidence supports a role for inflammatory/immune components in OPC proliferation, recruitment and differentiation.

In a mouse model of traumatic injury, Rhodes and colleagues have established that, amongst early factors capable to induce immediate reactivity in OPC in the form of NG2 upregulation, hypertrophy and increase in OPC cell number, are blood-derived macrophages in a defined activation state including the release of the inflammatory cytokines TNFa, IL1a, TGF $\beta$, INFY (Rhodes et al., 2006). Furthermore, specific macrophage/microglia activation phenotypes have been proposed to differentially affect OPC proliferation and regenerative capabilities through the selective activation of specific microglia/macrophage TLRs (Lehenardt et al., 2002; Glezer et al., 2006; Schonberg et al., 2007; Taylor et al., 2010). Despite data presented in distinct studies are not completely consistent (perhaps due to different experimental conditions), the consensus view is that defined microglia/macrophage activation states, correlated with specific pattern of cytokine production, act by either triggering or hampering OPC proliferation and differentiation. For instance, IL4-stimulated microglia has been shown to promote oligodendrogenesis from local progenitors in an autoimmune demyelination models, whereas INF $\gamma$-stimulated microglia had no or very limited effects (Butovsky et al., 2005). The role of innate immunity in OPC functioning in damage has further been substantiated by studies on non-immunity-mediated toxin-induced models of focal demyelination. In these models, genetic-based depletion or pharmacological inhibition of macrophages leads to an impairment of remyelination (Kotter et al., 2001, 2005), indicating a defective OPC response in an injury condition that normally leads to complete regeneration of myelinating oligodendrocytes by local reactive OPCs (Woodruff and Franklin, 1999). In the same experimental lesion, enhancing TLR4 mediated microglia activation by LPS infusion increases OPC reactivity, promotes a more efficient removal of myelin debris and triggers a faster appearance of remyelination markers (Glezer et al., 2006). It is clear that one key aspect of the innate immunity contribution to the full expression of the OPC regenerative potential is the removal of myelin debris. In vitro and in vivo data support the notion that myelin components dampen OPC differentiation (Miller, 1999). In line with these findings, anti-inflammatory drugs attenuating microglia/macrophage activity can affect OPC responses by delaying their differentiation in experimental demyelination ( $\mathrm{Li}$ et al., 2005; Chari et al., 2005).

A similar role in the modulation of OPC reaction to demyelination has been attributed to $\mathrm{T}$ cells (both $\mathrm{CD}^{+}+$and $\mathrm{CD} 8+$ ) indicating that also adaptive immunity is required for the correct OPC regenerative response (Bieber et al., 2003). Indeed, lack or depletion of either 
CD4+ or CD8+ is associated with reduced remyelination in focal demyelination. Interestingly, the disease-delaying drug Glatiramer acetate (GA) adopted for therapy in MS, may promote remyelination by potentiating a specific $\mathrm{T}$ cell mediated effects. Indeed, it has been shown in vitro that GA increases the production of Th2 cells, IGF1, and that the conditioned medium from GA-reactive $\mathrm{T}$ cells promotes the formation of OPCs from embryonic brain-derived forebrain cell culture. These findings are confirmed in vivo, where GA increases the OPC number and the extent of remyelinaton in toxin-mediated focal demyelination (Skihar et al., 2009).

Moving from cells to molecular signals, a wide range of pro-inflammatory cytokines (e.g. IL1 $\beta$ and TNF $\alpha$, along with lymphotoxin- $\beta$ receptor and MHCII) have been implicated as mediators of remyelination in non-autoimmune remyelination, implying that they promote the reactivity and the reparative behaviour of OPCs (revised in Franklin and ffrench-Costant, 2008). Another cytokine, INFY, has instead been shown to inhibit remyelination (Franklin and ffrench-Costant, 2008). In turn, upon INFY stimulation glial precursors with features of OPCs have been shown to produce a variety of immunomodulators, trophic factors, microglia attractive factors, and activate the expression of specific TLRs (Cassiani-Ingoni et al., 2006), indicating that OPC participate in active and bidirectional interplay with immune cells. Finally, cytokines have also been proposed as capable to instruct alternative OPC fates: in vitro exposure to INFY diverted glial progenitor from oligodendrogenesis to astrogliogenesis. Despite this finding is consistent with the capability of INF $\gamma$ to block remyelination, astrogliogenesis from OPCs in vivo remains debated (see above).

Moving to injury models distinct from demyelination, spinal cord contusions offer an example of a traumatic injury where intense OPC proliferation is not accompanied by complete glial repopulation of the lesioned area. In this specific immuno-inflammatory condition, activated microglia/macrophages have been shown to secrete inhibitory factors (i.e. TNF $\alpha$, and extracellular matrix modifiers) hampering survival and growth of OPC ex vivo, and impeding their migration into the lesioned demyelinated area ( $\mathrm{Wu}$ et al., 2010). Opposite effects of activated microglia on tissue repair in different lesion models may indeed be explained by different timing of recruitment of $\mathrm{T}$ cells in this process ensuing distinct microglia activation states (following Schwartz and Yoles, 2006).

Immuno-inflammatory levels have also been suggested to affect the neurogenic potential of parenchymal precursors, independent on their identity. Low levels of inflammation or specific immuno/inflammatory states have been proposed to allow the disclosure of neurogenic potentialities. In the cerebral cortex, selective cortical neuron damage mediated by apoptotic events and very low levels of inflammatory/immune activation has been associated with the appearance of glial cells with radial progenitor traits and rare immature neurons, suggesting that injury-induced de-differentiatiation of resident astrocytes to a radial glia state may subserve local neurogenesis (Leavitt et al., 1999; Chen et al., 2004). Also mild ischemic damage has been reported to allow neurogenesis from parenchymal sources: viral-based tracing revealed that layer I cortical progenitors can give birth to a low number of GABAergic cortical interneurons (Ohira et al., 2010).

A further support to the contention that local immune response strongly influences the behaviour of local precursors was provided by the observation in a model of spinal cord 
lesion that combined modulation of $\mathrm{T}$ cell activation by myelin-derived peptide vaccination and transplantation of immunomodulatory adult NSCs correlated with the appearance of neurogenic attempts from local progenitors accompanied by modulation of parenchymal $\mathrm{T}$ cell response and microglia activation, and, increased BDNF and noggin expression (Ziv et al., 2006b). Pioneering studies have also started investigating the influence of $\mathrm{T}$ cells on astrocytes, showing that $\mathrm{T}$-cell derived signals modify the astrocytic metabolic state in vitro. Namely, glutamate released by $\mathrm{T}$ cells promotes the acquisition of a neuroprotective phenotype and potentiates their capability to clear glutamate (Garg et al., 2008). Astroglial dysfunctions appear instead induced by LPS-activated microglia in vivo, resulting in defect of the BBB and subsequent myelin damage (Sharma et al., 2010). Astrocytes are obviously intensely involved in any kind of response to noxious stimuli, given their essential functions in the maintenance of tissue homeostatis, scavenging of toxic molecules, production of trophic support to neurons and oligodendrocytes, and cytogenic glial scarring to prevent the spreading of potential secondary damage to the healthy tissue (Buffo et al., 2010). The astrocytic reaction is directly or indirectly induced by various inflammatory cytokines and, in turn, reactive astrocytes produce proinflammatory molecules that modulate their own activation state and that of immune cells (Buffo et al., 2010; Kostianovsky et al., 2008). Whether and how inflammatory/immune factors specifically affect the progenitor potential of reactive astroglia is not known. What is well accepted is that extended damage is associated with high levels of inflammation and immune activation that are generally unfavourable to the disclosure of progenitor properties and regeneration (see also above). Accordingly, controlled microlesions to the CNS and associated low levels of inflammatory/immuno activation were reported to induce immature/progenitor phenotypes associated with rare neurogenic events as well as the establishment of a microenvironment more prone to support axon growth (Leavitt et al., 1999; Chen et al., 2004). It remains to be established whether specific components or modalities of innate/adaptive immune activation can boost such pro-reparative changes in resident astroglia in case of extended damage. On the whole, these data indicate that the expression of the reparative potentials of parenchymal progenitors can be supported by immune mechanisms directed at both removing debris and toxic molecules, and performing immunomodulation to avoid the overactivation of the immune response.

\section{Concluding remarks}

Recent discoveries have profoundly changed the perception of CNS-immune interactions. In particular, the novel roles of immune cells in the maintenance and plastic regulation of adult NSC functions have revealed an unexpected exchange of signals between the nervous and immune systems, opening the possibility that immune malfunction may have relevance in so far unsuspected CNS diseases. Furthermore, a decade of investigations has dissected components of the immune response to CNS injury that potentiate or dampen CNS reparative activities. While more research is needed to disclose the influence of immune factors on the properties of parenchymal sources of progenitor cells, on the whole immune cells can be proposed as an endogenous therapeutic target to modulate immune mechanisms on the part beneficial to foster CNS repair and function restoration. 


\section{Acknowledgments}

Chiara Rolando' s fellowship and work in our laboratory are supported by Compagnia di San Paolo, GLIAREP project.

\section{References}

Aarum, J., Sandberg, K., Haeberlein, S.L.B., Persson, M.A.A. (2003). Migration and differentiation of neural precursor cells can be directed by microglia. Proceedings of the National Academy of Sciences USA, Vol.100, No.26 (Dec 2003), pp. 15983-15988, ISSN 1091-6490.

Aloisi, F., Ria, F., \& Adorini, L. (2000). Regulation of T-cell responses by CNS antigenpresenting cells: different roles for microglia and astrocytes. Immunology today, Vol.21, No.3 (Mar 2000), pp. 141-147, ISSN 0167-5699.

Bakiri, Y., Attwell, D,. \& Káradóttir, R. (2009). Electrical signalling properties of oligodendrocyte precursor cells. Neuron Glia Biology, Vol.5, No.1-2 (May 2009), pp. 3-11, ISSN 1740-925X.

Barnabé-Heider, F., Göritz, C., Sabelström, H., Takebayashi, H., Pfrieger, F.W., Meletis, K., \& Frisén, J. (2010). Origin of new glial cells in intact and injured adult spinal cord. Cell Stem Cell. Vol.7, No.4 (Oct 2010), pp. 470-82, ISSN 19345909.

Battista, D., Ferrari, C.C., Gage, F.H., \& Pitossi, F.J. (2006). Neurogenic niche modulation by activated microglia: transforming growth factor $\beta$ increases neurogenesis in the adult dentate gyrus. European Journal of Neuroscience, Vol.23, No.1 (Jan 2006), pp. 8393, ISSN 1460-9568.

Becher, B., Prat, A., \& Antel, J.P. (2000). Brain-immune connection: immuno-regulatory properties of CNS-resident cells. Glia, Vol.29, No.4 (Feb 2000), pp. 293-304, ISSN 1098-1136.

Bechmann, I., Mor, G., Nilsen, J., Eliza, M., Nitsch, R., \& Naftolin, F. (1999). FasL (CD95L, Apo1L) is expressed in the normal rat and human brain: evidence for the existence of an immunological brain barrier. Glia, Vol.27, No.1 (Jul 1999), pp.62-74, ISSN 1098-1136.

Beers, D.R., Henkel, J.S., Zhao, W., Wang, J., \& Appel, S.H. (2008). CD4+ T cells support glial neuroprotection, slow disease progression, and modify glial morphology in an animal model of inherited ALS. Proceedings of the National Academy of Sciences USA, Vol.105, No.40 (Oct 2008), pp. 15558-15563, ISSN 0027-8424.

Bieber, A. J., Kerr, S. \& Rodriguez, M. Efficient central nervous system remyelination requires T cells. (2003). Annals of Neurology, Vol.53, No.5 (May 2003), pp. 680-684, 531-8249.

Billingham, R.E., Boswell, T. (1953). Studies on the problem of corneal homografts. Proceeding of the Royal Society Biological Science, Vol.141, No.904, pp. 392-406, ISSN 1471-2954.

Boda, E., Buffo, A. (2010) Glial cells in non-germinal territories: insights into their stem/progenitor properties in the intact and injured nervous tissue. Archives Italiennes de Biologie, Vol. 148, No.2 (June 2010), pp 119-136, ISSN 0003-9829.

Buffo, A., Rite, I., Tripathi, P., Lepier, A., Colak, D., Horn, A.P., Mori, T., \& Götz M. (2008). Origin and progeny of reactive gliosis: A source of multipotent cells in the injured 
brain. Proceedings of the National Academy of Sciences U S A. Vol.105, No.9 (Mar 2008), pp. 3581-3586, ISSN 0027-8424.

Buffo, A., Rolando, C., \& Ceruti, S. (2010). Astrocytes in the damaged brain: molecular and cellular insights into their reactive response and healing potential. Biochemical Pharmacology, Vol.79, No.2 (Jan 2010), pp. 77-89, ISSN 0006-2952.

Bush, T.G., Puvanachandra, N., Horner, C.H., Polito, A., Ostenfeld, T., Svendsen, C.N., Mucke, L., Johnson, M.H., \& Sofroniew, M.V. (1999). Leukocyte infiltration, neuronal degeneration, and neurite outgrowth after ablation of scar-forming, reactive astrocytes in adult transgenic mice. Neuron, Vol.23 No.2 (Jun 1999), pp. 297-308. ISSN 0896-6273.

Butovsky, O., Talpalar, A.E., Ben-Yaakov, K., \& Schwartz, M. (2005). Activation of microglia by aggregated $\beta$-amyloid or lipopolysaccharide impairs MHC-II expression and renders them cytotoxic whereas IFN- $\gamma$ and IL-4 render them protective. Molecular and Cellular Neuroscience, Vol.29, No.3 (Jul 2005), pp. 381-393, ISSN 1044-7431.

Butovsky, O., Landa, G., Kunis, G., Ziv, Y., Avidan, H., Greenberg, N., Schwartz, A., Smirnov, I., Pollack, A., Jung, S., \& Schwartz, M. (2006). Induction and blockage of oligodendrogenesis by differently activated microglia in an animal model of multiple sclerosis. Journal of Clinical Investigation, Vol.116, No.4 (Mar 2006), pp. 905915, ISSN 00219738.

Carpentier, P.A., Begolka, W.S., Olson, J.K., Elhofy, A., Karpus, W.J., \& Miller, S.D. (2005). Differential activation of astrocytes by innate and adaptive immune stimuli. Glia, Vol.49, No.3 (Feb 2005), pp. 360-374, ISSN 1098-1136.

Carpentier, P.A., \& Palmer, T.D. (2009). Immune Influence on Adult Neural Stem Cell Regulation and Function. Neuron, Vol.64, No.1 (Oct 2009), pp. 79-92, ISSN 08966273.

Cassiani-Ingoni, R., Coksaygan, T., Xue, H., Reichert-Scrivner, S.A., Wiendl, H., Rao, M.S., \& Magnus, T. (2006). Cytoplasmic translocation of Olig2 in adult glial progenitors marks the generation of reactive astrocytes following autoimmune inflammation. Experimental Neurology, Vol.201, No.2 (Oct 2006), pp. 349-58, ISSN 0014-4886.

Chari, D. M., Zhao, C., Kotter, M. R., Blakemore, W. F. \& Franklin, R. J. M. (2006). Corticosteroids delay remyelination of experimental demyelination in the rodent central nervous system. Journal of Neuroscience Research, Vol.83, No.4 (Mar 2006), pp. 594-605, ISSN 1097-4547.

Chen, J., Magavi, S.S., \& Macklis, J.D. (2004). Neurogenesis of corticospinal motor neurons extending spinal projections in adult mice. Proceedings of the National Academy of Sciences U S A, Vol.101, No.46 (Nov 2004), pp. 16357-16362, ISSN 0027-8424.

Choi, C., Benveniste, E.N. (2004). Fas ligand/Fas system in the brain: regulator of immune and apoptotic responses. Brain Research Review, Vol.44, No.1 (Jan 2004), pp. 65-81, ISSN 0165-0173.

Dawson MR, Polito A, Levine JM, \& Reynolds, R. (2003). NG2-expressing glial progenitor cells: an abundant and widespread population of cycling cells in the adult rat CNS. Molecular Cellular Neuroscience, Vol.24, No.2 (Oct 2003), pp.476-88, ISSN 1044-7431.

Deierborg, T., Roybon, L., Inacio, A.R., Pesic, J., \& Brundin, P. (2010). Brain injury activates microglia that induce neural stem cell proliferation ex vivo and promote differentiation of neurosphere-derived cells into neurons and oligodendrocytes. Neuroscience, Vol.171, No.4 (Dec 2010), pp. 1386-1396, ISSN 03064522. 
Dittel, B.N. (2008). CD4 T cells: Balancing the coming and going of autoimmune-mediated inflammation in the CNS. Brain, Behavior, and Immunity, Vol.22, pp. 421-430, ISSN 0889-1591.

Donnelly, D.J., Popovich, P.G. (2007). Inflammation and its role in neuroprotection, axonal regeneration and functional recovery after spinal cord injury. Experimental Neurology, Vol.209, No.2 (Feb 2008), pp. 378-388, ISSN 0014-4886.

Ekdahl, C.T., Kokaia, Z., \& Lindvall, O. (2009). Brain inflammation and adult neurogenesis: The dual role of microglia. Neuroscience, Vol.158, No.3 (Feb 2009), pp. 1021-1029, ISSN 03064522.

Engelhardt, B., Ransohoff, R.M. (2005). The ins and outs of T-lymphocyte trafficking to the CNS: anatomical sites and molecular mechanisms. Trends in Immunology, Vol.26, No.9 (Sep 2005), pp. 485-495, ISSN 1471-4906.

Fabry Z, Raine CS, \& MN, H. (1994). Nervous tissue as an immune compartment: the dialect of the immune response in the CNS. Immunology Today, Vol.15, No.5 (May 1994), pp. 218-224, ISSN 0167-5699.

Fabry, Z., Schreiber, H.A., Harris, M.G., \& Sandor, M. (2008). Sensing the microenvironment of the central nervous system: immune cells in the central nervous system and their pharmacological manipulation. Current Opinion in Pharmacology, Vol.8, pp. 496-507, ISSN 1471-4892.

Farina, C., Aloisi, F., \& Meinl, E. (2007). Astrocytes are active players in cerebral innate immunity. Trends in Immunology, Vol.28, No.3 (Feb 2007), pp. 138-145, ISSN 14714906.

Fisher, J., Levkovitch-Verbin, H., Schori, H., Yoles, E., Butovsky, O., Kaye, J.F., Ben-Nun, A., \& Schwartz, M. (2001). Vaccination for neuroprotection in the mouseoptic nerve: implications for optic neuropathies. Journal of Neuroscience, Vol.21, No.1 (Jan 2001), pp. 136-142, ISSN 0270-6474.

Franklin, R.J., \& Ffrench-Constant, C. (2008). Remyelination in the CNS: from biology to therapy. Nature Reviews Neuroscience, Vol.9, No.11 (Nov 2008), pp. 839-55, ISSN 1471-003X.

Fröhlich, N., Nagy, B., Hovhannisyan, A., \& Kukley, M. (2011). Fate of neuron-glia synapses during proliferation and differentiation of NG2 cells. Journal of Anatomy, Vol.219, No.1 (Jul 2011), pp. 18-32, ISSN 1469-7580.

Galea, I., Bechmann, I., \& Perry, V.H. (2007). What is immune privilege (not)? Trends in Immunology, Vol.28, No.1 (Jan 2007) pp. 12-18, ISSN 1471-4906.

Garg, S.K., Banerjee, R., \& Kipnis, J. (2008). Neuroprotective immunity: T cell-derived glutamate endows astrocytes with a neuroprotective phenotype. Journal of Immunology, Vol.180, No.6 (Mar 2008), pp. 3866-3873, ISSN 0022-1767.

Glezer, I., Lapointe, A., \& Rivest, S. (2006). Innate immunity triggers oligodendrocyte progenitor reactivity and confines damages to brain injuries. FASEB Journal, Vol.20, No.6 (Apr 2006), pp.750-2, ISSN 0892-6638.

Goings, G.E., Kozlowski, D.A., \& Szele, F.G. (2006). Differential activation of microglia in neurogenic versus non-neurogenic regions of the forebrain. Glia, Vol.54, No.4 (Sept 2006), pp. 329-342, ISSN 1098-1136.

Goverman, J. (2009). Autoimmune T cell responses in the central nervous system. Nature Review Immunology, Vol.9, No.6 (Jun 2009), pp. 393-407, ISSN 1474-1733. 
Griffiths, M., Neal, J.W., Gasque, P., Giacinto Bagetta, M.T.C., \& Stuart, A.L. (2007). Innate Immunity and Protective Neuroinflammation: New Emphasis on the Role of Neuroimmune Regulatory Proteins. International Review of Neurobiology, Vol.82, pp. 29-55, ISSN 0074-7742.

Hampton, D.W., Rhodes, K.E, Zhao, C., Franklin, RJ, Fawcett, J.W. (2004) The responses of oligodendrocyte precursor cells, astrocytes and microglia to a cortical stab injury, in the brain. Neuroscience. Vol.127, No.4 (Jul 2004), pp. 813-20, ISSN 0306-4522.

Hauben, E., Butovsky, O., Nevo, U., Yoles, E., Moalem, G., Agranov, E., Mor, F., LeibowitzAmit, R., Pevsner, E., Akselrod, S., Neeman, M., Cohen, I.R., \&Schwartz, M. (2000). Passive or active immunization with myelin basic protein promotes recovery from spinal cord contusion. Journal Neuroscience, Vol.20, No.17 (Sep 2000), pp. 6421-30, ISSN 0270-6474.

Hohlfeld, R., Kerschensteiner, M., Stadelmann, C., Lassmann, H., \& Wekerle, H. (2000). The neuroprotective effect of inflammation: implications for the therapy of multiple sclerosis. Journal of Neuroimmunology, Vol.107, No.2 (Jul 2000), pp.161-166, ISSN 0165-5728.

Horner ,P.J., Power, A.E., Kempermann. G., Kuhn, H.G., Palmer, T.D., Winkler, J., Thal, L.J., \& Gage, FH. (2000). Proliferation and differentiation of progenitor cells throughout the intact adult rat spinal cord. Journal of Neuroscience, Vol.20, No.6 (Mar 2000), pp. 2218-2228, ISSN 0270-6474.

Huang, X.Y., Reynolds, A.D., Mosley, R.L., \& Gendelman, H.E. (2009). CD 4+T cells in the pathobiology of neurodegenerative disorders. Journal of Neuroimmunology, Vol.211, No.1-2, pp. 3-15, ISSN 0165-5728.

Ishibashi, S., Maric, D., Mou, Y., Ohtani, R., Ruetzler, C., \& Hallenbeck, J.M. (2008). Mucosal tolerance to E-selectin promotes the survival of newly generated neuroblasts via regulatory T-cell induction after stroke in spontaneously hypertensive rats. Journal Cerebral Blood Flow Metabolism, Vol.29, No.3 (Mar 2009), pp. 606-620, ISSN 0271$678 X$.

Kaur, C., Ling, E.A. (2008). Blood brain barrier in hypoxic-ischemic conditions. Current Neurovascular Research, Vol.5, No.1 (Feb 2008), pp. 71-81, ISSN 1567-2026.

Keirstead, H.S., Levine, J.M., \& Blakemore, W.F. (1998). Response of the oligodendrocyte progenitor cell population (defined by NG2 labelling) to demyelination of the adult spinal cord. Glia, Vol.22, No.2 (Feb 1998), pp.161-170, ISSN 1098-1136.

Kettenmann H., \& Verkhratsky, A. (2008). Neuroglia: the 150 years after. Trends Neuroscience, Vol.31, No.12 (Dec 2008), pp.653-659, ISSN 0166-2236.

Kim, D.H., Kim, J.M., Park, S.J., Lee, S., Yoon, B.H., \& Ryu, J.H. (2010). Early-activated microglia play a role in transient forebrain ischemia-induced neural precursor proliferation in the dentate gyrus of mice. Neuroscience Letters, Vol.475, No.2 (May 2010), pp. 74-79, ISSN 0304-3940.

Kipnis, J., Mizrahi, T., Hauben, E., Shaked, I., Shevach, E., \& Schwartz, M. (2002). Neuroprotective autoimmunity: naturally occurring CD4+CD25+ regulatory T cells suppress the ability to withstand injury to the central nervous system. Proceedings of the National Academy of Sciences U S A. Vol. 99, No. 24 (Nov 2002), pp. 15620-5, ISSN 0027-8424. 
Kondo T., \& Raff, M. (2000). Oligodendrocyte precursor cells reprogrammed to become multipotential CNS stem cells. Science, Vol.289, No.5485 (Sep 2000), pp. 1754-1757, ISSN 0036-8075.

Kostianovsky, A.M., Maier, L.M., Anderson, R.C., Bruce, J.N., \& Anderson, D.E. (2008). Astrocytic regulation of human monocytic/microglial activation. Journal of Immunology, Vol.181, No.8 (Oct 2008), pp. 5425-5432, ISSN 0022-1767.

Kotter, M. R., Setzu, A., Sim, F. J., van Rooijen, N. \& Franklin, R. J. M. (2001). Macrophage depletion impairs oligodendrocyte remyelination following lysolecithin induced demyelination. Glia, Vol.35, No.3 (Sep 2001), pp. 204-212, ISSN 1098-1136.

Kotter, M. R., Zhao, C., van Rooijen, N. \& Franklin, R. J. M. (2005). Macrophage-depletion induced impairment of experimental CNS remyelination is associated with a reduced oligodendrocyte progenitor cell response and altered growth factor expression. Neurobiology of Disease, Vol.18, No.1 (Feb 2005), pp. 166-175, ISSN 0969-9961.

Kriegstein, A., \& Alvarez-Buylla, A. (2009). The glial nature of embryonic and adult neural stem cells. Annual Review of Neuroscience, Vol.32, pp. 149-184, ISSN 1545-4126.

Leavitt, B.R., Hernit-Grant, C.S., \& Macklis, J.D. (1999). Mature astrocytes transform into transitional radial glia within adult mouse neocortex that supports directed migration of transplanted immature neurons. Experimenal Neurology, Vol.157, No.1 (May 1999), pp. 43-57, ISSN 0022-3069.

Lehnardt, S., Lachance, C., Patrizi, S., Lefebvre, S., Follett, P.L., Jensen, F.E., Rosenberg, P.A., Volpe, J.J., \& Vartanian, T. (2002). The toll-like receptor TLR4 is necessary for lipopolysaccharide-induced oligodendrocyte injury in the CNS. Journal of Neuroscience, Vol.22, No.7 (Apr 2002), pp. 2478-86, ISSN 0270-6474.

Li, L., Walker, T.L., Zhang, Y., Mackay, E.W., \& Bartlett, P.F. (2010). Endogenous Interferon$\gamma$ Directly Regulates Neural Precursors in the Non-Inflammatory Brain. The Journal of Neuroscience, Vol.30, No.27 (Jul 2010) pp. 9038-9050, ISSN 0270-6474.

Li, W.W., Setzu, A., Zhao, C. \& Franklin, R. J. M. (2005). Minocycline-mediated inhibition of microglia activation impairs oligodendrocyte progenitor cell responses and remyelination in a non-immune model of demyelination. Journal of Neuroimmunology, Vol.158, No.1-2 (Jan 2005), pp. 58-66, ISSN 0165-5728.

Liao, H., Huang, W., Niu, R., Sun, L., \& Zhang, L. (2008). Cross-talk between the epidermal growth factor-like repeats/fibronectin 6-8 repeats domains of Tenascin- $R$ and microglia modulates neural stem/progenitor cell proliferation and differentiation. Journal of Neuroscience Research, Vol.86, No.1 (Jan 2008), pp. 27-34, ISSN 0360-4012.

Liesz, A., Suri-Payer, E., Veltkamp, C., Doerr, H,. Sommer, C., Rivest, S., Giese, T., \& Veltkamp, R. (2009). Regulatory $\mathrm{T}$ cells are key cerebroprotective immunomodulators in acute experimental stroke. Nature Medicine, Vol.15, No.2 (Feb 2009) pp. 192-199, ISSN 1078-8956.

Liu, Y.W., Teige, I., Birnir, B., \& Issazadeh-Navika, S. (2006). Neuron-mediated generation of regulatory T cells from encephalitogenic T cells suppresses EAE. Nature Medicine, Vol.12, No.5 (May 2006), pp. 518-525, ISSN 1078-8956.

McFarland, H.F., Martin, R. (2007). Multiple sclerosis: a complicated picture of autoimmunity. Nature Immunology, Vol.8, No.9 (Sep 2007), pp. 913-919, ISSN 1529-2908.

McMahon, E.J., Bailey, S.L., \& Miller, S.D. (2006). CNS dendritic cells: critical participants in CNS inflammation? Neurochemistry International, Vol.49, No.2, pp. 195-203, ISSN 0197-0186. 
Meinl, E., Krumbholz, M., \& Hohlfeld, R. (2006). B lineage cells in the inflammatory central nervous system environment: Migration, maintenance, local antibody production, and therapeutic modulation. Annals of Neurology, Vol.59, No.6 (Jun 2006), pp. 880892, ISSN 0364-5134.

Miller, R.H. (1999). Contact with central nervous system myelin inhibits oligodendrocyte progenitor maturation. Developmental Biology, Vol.216, No.1 (Dec 1999), pp. 359368, ISSN 0012-1606.

Moalem, G., Leibowitz-Amit, R., Yoles, E., Mor, F., Cohen, I.R., \& Schwartz, M. (1999). Autoimmune $\mathrm{T}$ cells protect neurons from secondary degeneration after central nervous system axotomy. Nature Medicine, Vol.5, No.1 (Jan 1999), pp. 49-55, ISSN 1078-8956.

Monje, M.L., Toda, H., \& Palmer, T.D. (2003). Inflammatory Blockade Restores Adult Hippocampal Neurogenesis. Science, Vol.302, No.5651 (Dec 2003), pp. 1760-1765, ISSN 1095-9203.

Moriyama, M., Fukuhara, T., Britschgi, M., He, Y., Narasimhan, R., Villeda, S., Molina, H., Huber, B.T., Holers, M., \& Wyss-Coray, T. (2011). Complement receptor 2 is expressed in neural progenitor cells and regulates adult hippocampal neurogenesis. The Journal of Neuroscience, Vol.31, No.11 (Mar 2011), pp. 3981-3989, ISSN 0270-6474.

Nguyen, M.D., Julien, J.P., \& Rivest, S. (2002). Innate immunity: the missing link in neuroprotection and neurodegeneration? Nature Review Neuroscience, Vol.3, No.3 (Mar 2002), pp. 216-227, ISSN 1471-0048.

Nimmerjahn, A., Kirchhoff, F., \& Helmchen, F. (2005). Resting microglial cells are highly dynamic surveillants of brain parenchyma in vivo. Science, Vol.308, No.5726 (May 2005), pp. 271314-271318.

Ohira, K., Furuta, T., Hioki, H., Nakamura, K.C., Kuramoto, E., Tanaka, Y., Funatsu, N., Shimizu, K., Oishi, T., Hayashi, M., Miyakawa, T., Kaneko, T., \& Nakamura, S. (2010) Ischemia-induced neurogenesis of neocortical layer 1 progenitor cells. Nature Neuroscience, Vol.13, No.2 (Feb 2010), pp. 173-179, ISSN 1097-6256.

Olah, M., Ping, G., De Haas, A.H., Brouwer, N., Meerlo, P., Van Der Zee, E.A., Biber, K., \& Boddeke, H.W.G.M. (2009). Enhanced hippocampal neurogenesis in the absence of microglia $\mathrm{T}$ cell interaction and microglia activation in the murine running wheel model. Glia, Vol.57, No.10 (Aug 2010), pp. 1046-1061, ISSN 1098-1136.

Parijs, L.V., Abbas, A.K. (1998). Homeostasis and self-tolerance in the immune system: turning lymphocytes off. Science, Vol.280, No.5361 (Apr 1998), pp. 243-248, ISSN 1095-9203.

Pluchino, S., Muzio, L., Imitola, J., Deleidi, M., Alfaro-Cervello, C., Salani, G., Porcheri, C., Brambilla, E., Cavasinni, F., Bergamaschi, A., Garcia-Verdugo, J.M., Comi, G., Khoury, S.J., \& Martino, G. (2008). Persistent inflammation alters the function of the endogenous brain stem cell compartment. Brain, Vol.131, No.10 (Oct 2010), pp. 2564-2578, ISSN 1460-2156.

Popa, N., Cedile, O., Pollet-Villard, X., Bagnis, C., Durbec, P., Boucraut, J.E. (2011). RAE-1 is expressed in the adult subventricular zone and controls cell proliferation of neurospheres. Glia, Vol.59, No.1 (Jan 2011), pp. 35-44, ISSN 1098-1136.

Rahpeymai, Y., Hietala, M.A., Wilhelmsson, U., Fotheringham, A., Davies, I., Nilsson, A.-K., Zwirner, J., Wetsel, R.A., Gerard, C., Pekny, M., \& Pekna, M. (2006). Complement: a 
novel factor in basal and ischemia-induced neurogenesis. EMBO Journal, Vol.25, No.6 (Mar 2006), pp. 1364-1374, ISSN 1460-2075.

Ransohoff, R.M., Kivisakk, P., \& Kidd, G. (2003). Three or more routes for leukocyte migration into the central nervous system. Nature Review Immunology, Vol.3, No.7 (Jul 2007), pp. 569-581, ISSN 1474-1733.

Rapalino, O., Lazarov-Spiegler, O., Agranov, E., Velan, G.J., Yoles, E., Fraidakis, M., Solomon, A., Gepstein, R., Katz, A., Belkin, M., Hadani, M., \& Schwartz, M. (1998). Implantation of stimulated homologous macrophages results in partial recovery of paraplegic rats. Nature Medicine, Vol.4, No.7 (Jul 1998), pp. 814-21, ISSN 1078-8956.

Rasmussen, S., Imitola, J., Ayuso-Sacido, A., Wang, Y., Starossom, S.C., Kivisäkk, P., Zhu, B., Meyer, M., Bronson, R.T., Garcia-Verdugo, J.M., \& Khoury, S.J. (2011). Reversible neural stem cell niche dysfunction in a model of multiple sclerosis. Annals of Neurology, Vol.69, No.5 (May 2011), pp. 878-891, ISSN 1531-8249.

Reddy, J., Illes, Z., Zhang, X., Encinas, J., Pyrdol, J., Nicholson, L., Sobel, R.A., Wucherpfennig, K.W., \& Kuchroo, V.K. (2004). Myelin proteolipid protein-specific CD4+CD25+ regulatory cells mediate genetic resistance to experimental autoimmune encephalomyelitis. Proceedings of the National Academy of Sciences $U S$ A, Vol.101, No.43 (Oct 2004), pp. 15434-15439, ISSN 0027-8424.

Reynolds, R., Dawson, M., Papadopoulos, D., Polito, A., Di Bello, I.C., Pham-Dinh, D., \& Levine J. (2002) The response of NG2-expressing oligodendrocyte progenitors to demyelination in MOG-EAE and MS. Journal Neurocytology, Vol.31, No.6-7 (Jul-Aug 2002), pp.523-536, ISSN 0300-4864.

Rhodes, K.E., Raivich, G, \& Fawcett, J.W. (2006). The injury response of oligodendrocyte precursor cells is induced by platelets, macrophages and inflammation-associated cytokines. Neuroscience, Vol.14, No.1 (Jun 2006), pp. 87-100, ISSN 03064522.

Richardson, WD, Young, K.M., Tripathi, R.B., \& McKenzie, I. (2011). NG2-glia as multipotent neural stem cells: fact or fantasy? Neuron. Vol.70, No.4 (May 2011), pp. 661-673, ISSN 0896-6273.

Rolls, A., Shechter, R., London, A., Ziv, Y., Ronen, A., Levy, R., \& Schwartz, M. (2007). Tolllike receptors modulate adult hippocampal neurogenesis. Nature Cell Biology, Vol.9, No.9 (Sep 2007), pp. 1081-1088, ISSN 1465-7392.

Saino, O., Taguchi, A., Nakagomi, T., Nakano-Doi, A., Kashiwamura, S.I., Doe, N., Nakagomi, N., Soma, T., Yoshikawa, H., Stern, D.M., Okamura, H., \& Matsuyama, T. (2010). Immunodeficiency reduces neural stem/progenitor cell apoptosis and enhances neurogenesis in the cerebral cortex after stroke. Journal of Neuroscience Research, Vol.88, No.11 (Aug 2011), pp. 2385-2397, ISSN 0360-4012.

Schonberg, D.L., Popovich, P.G., \& McTigue, D.M. (2007). Oligodendrocyte generation is differentially influenced by toll-like receptor (TLR) 2 and TLR4-mediated intraspinal macrophage activation. Journal Neuropathology Experimental Neurology Vol.66, No.12 (Dec 2007), pp. 1124-35, ISSN 0022-3069.

Schwartz, M., \& Yoles, E. (2006). Immune-based therapy for spinal cord repair: autologous macrophages and beyond. Journal Neurotrauma, Vol.23, No.3-4 (Apr 2006), pp. 360370, ISSN- 1557-9042.

Schwartz, M., A., \& Shechter, R. (2009). Boosting T-cell immunity as a therapeutic approach for neurodegenerative conditions: the role of innate immunity. Neuroscience, Vol.158, No.3 (Febr 2009), pp. 1133-1142, ISSN 03064522. 
Schwartz, M., \& Shechter, R. (2010). Systemic inflammatory cells fight off neurodegenerative disease. Nature Review in Neurology, Vol.6, No.7 (Jul 2010) pp. 405-10, ISSN 1759-4758.

Shaked, I., Tchoresh, D., Gersner, R., Meiri, G., Mordechai, S., Xiao, X., Hart, R.P., \& Schwartz, M. (2005). Protective autoimmunity: interferon-gamma enables microglia to remove glutamate without evoking inflammatory mediators. Journal of Neurochemistry, Vol.92, No.5 (Mar 2005), pp. 997-1009, ISSN 0022-3042.

Sharma, R., Fischer, M.T., Bauer, J., Felts, P.A., Smith, K.J., Misu, T, Fujihara, K., Bradl, M., \& Lassmann, H. (2010). Inflammation induced by innate immunity in the central nervous system leads to primary astrocyte dysfunction followed by demyelination. Acta Neuropathologica, Vol.120, No.2 (Aug 2010), pp. 223-236, ISSN 0001-6322.

Shechter, R., London, A., Varol, C., Raposo, C., Cusimano, M., Yovel, G., Rolls, A., Mack, M., Pluchino, S., Martino, G., Jung, S., \& Schwartz, M. (2009). Infiltrating blood-derived macrophages are vital cells playing an anti-inflammatory role in recovery from spinal cord injury in mice. PLoS Medicine, Vol.6, No.7 (Jul 2009), ISSN 1549-1676.

Sierra, A., Encinas, J.M., Deudero, J.J.P., Chancey, J.H., Enikolopov, G., Overstreet-Wadiche, L.S., Tsirka, S.E., \& Maletic-Savatic, M. (2010). Microglia Shape Adult Hippocampal Neurogenesis through Apoptosis-Coupled Phagocytosis. (2010). Cell Stem Cell, Vol.7, No.4 (Oct 2010), pp. 483-495, ISSN 1934-5909.

Skihar, V., Silva, C., Chojnacki, A., Döring, A., Stallcup, W.B., Weiss, S., Yong, V.W. (2009). Promoting oligodendrogenesis and myelin repair using the multiple sclerosis medication glatiramer acetate. Proceedings of the National Academy of Sciences U S A. Vol.106, No.42 (Oct 2009), pp. 17992-17997, ISSN 0027-8424.

Song, C., \& Wang, H. Cytokines mediated inflammation and decreased neurogenesis in animal models of depression. (2011). Progress in Neuro-Psychopharmacology and Biological Psychiatry, Vol.35, No.3 (Apr 2011) pp. 760-768, ISSN 0278-5846.

Spulber, S., Oprica, M., Bartfai, T., Winblad, B., \& Schultzberg, M. (2008). Blunted neurogenesis and gliosis due to transgenic overexpression of human soluble IL-1ra in the mouse. European Journal of Neuroscience, Vol.27, No.3 (Feb 2008), pp. 549-558, ISSN 1460-9568.

Starossom, S.C., Imitola, J., Wang, Y., Cao, L., Khoury, S.J. (2011). Subventricular zone microglia transcriptional network. Brain Behaviour Immunology, Vol.25, No.5 (Nov 2010), pp. 991-999, ISSN 0889-1591.

Taylor, D.L., Pirianov, G., Holland, S., McGinnity, C.J., Norman, A.L., Reali, C., Diemel, L.T., Gveric, D., Yeung, D., \& Mehmet, H. (2010). Attenuation of proliferation in oligodendrocyte precursor cells by activated microglia. Journal of Neuroscience Research, Vol.88, No.8 (Jun 2010), pp.1632-44, ISSN 1097-4547.

Trotter, J., Karram, K., \& Nishiyama, A. NG2 cells: Properties, progeny and origin. (2003). Brain Research Reviews, Vol.63, No.1-2 (May 2003), pp. 72-82, ISSN 0165-0173.

Vignali, D.A.A., Collison, L.W., \& Workman, C.J. (2008). How regulatory T cells work. Nature Review Immunology, Vol.8, No.7 (July 2008), pp. 523-532, ISSN 1474-1733.

Voskuhl, R.R., Peterson, R.S., Song, B., Ao, Y., Morales, L.B., Tiwari-Woodruff, S., \& Sofroniew, M.V. (2009). Reactive astrocytes form scar-like perivascular barriers to leukocytes during adaptive immune inflammation of the CNS. Journal of Neuroscience, Vol.29, No.37 (Sep 2009), pp. 11511-11522, ISSN 0270-6474.

Walsh, J.T., Kipnis, J. (2010). Regulatory T cells in CNS injury: the simple, the complex and the confused. Trends in Molecular Medicine, In Press, Corrected Proof, ISSN 1471-4914. 
Walton, N.M., Sutter, B.M., Laywell, E.D., Levkoff, L.H., Kearns, S.M., Marshall, G.P., Scheffler, B., \& Steindler, D.A. (2006). Microglia instruct subventricular zone neurogenesis. Glia, Vol.54, No.8 (Dec 2006), pp. 815-825, ISSN 1098-1136.

Wolf, S.A., Steiner, B., Akpinarli, A., Kammertoens, T., Nassenstein, C., Braun, A., Blankenstein, T., \& Kempermann, G. (2009). CD4-Positive T Lymphocytes Provide a Neuroimmunological Link in the Control of Adult Hippocampal Neurogenesis. The Journal of Immunology, Vol.182, No.7 (Apr 2009), pp. 3979-3984, ISSN 0165-5728.

Woodruff, R.H., \& Franklin, R.J. (1999). Demyelination and remyelination of the caudal cerebellar peduncle of adult rats following stereotaxic injections of lysolecithin, ethidium bromide, and complement/anti-galactocerebroside: a comparative study. Glia, Vol.25, No.1 (Feb 1999), pp. 216-228, ISSN 1098-1136.

Wu, J., Yoo, S., Wilcock, D., Lytle, J.M., Leung, P.Y., Colton, C.A., \& Wrathall, J.R. (2010). Interaction of NG2(+) glial progenitors and microglia/macrophages from the injured spinal cord. Glia, Vol.58, No.4 (Mar 2010), pp. 410-22, ISSN 1098-1136.

Yang, I., Han, S.J., Kaur, G., Crane, C., \& Parsa, A.T. (2010). The role of microglia in central nervous system immunity and glioma immunology. Journal of Clinical Neuroscience, Vol.17, No.1, pp. 6-10, ISSN 0967-5868.

Yirmiya, R., \& Goshen, I. Immune modulation of learning, memory, neural plasticity and neurogenesis. (2011). Brain, Behavior, and Immunity, Vol.25, No.2 (Feb 2011), pp. 181213, ISSN 0889-1591.

Zhao, C., Deng, W., \& Gage, F.H. (2008). Mechanisms and functional implications of adult neurogenesis. Cell, Vol.132, No.4 (Feb 2008), pp. 645-660.

Ziv, Y., Ron, N., Butovsky, O., Landa, G., Sudai, E., Greenberg, N., Cohen, H., Kipnis, J., \& Schwartz, M. (2006a). Immune cells contribute to the maintenance of neurogenesis and spatial learning abilities in adulthood. Nature Neuroscience, Vol.9, No.2 (Feb 2006), pp. 268-275, ISSN 1097-6256.

Ziv, Y., Avidan, H., Pluchino, S., Martino, G., \& Schwartz, M. (2006b). Synergy between immune cells and adult neural stem/progenitor cells promotes functional recovery from spinal cord injury. Proceedings of the National Academy of Sciences US A. Vol.103, No.35 (Aug 2006), pp. 13174-13179, ISSN 0027-8424. 


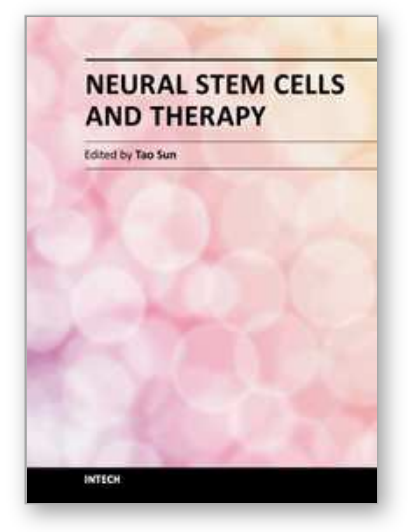

\author{
Neural Stem Cells and Therapy \\ Edited by Dr. Tao Sun
}

ISBN 978-953-307-958-5

Hard cover, 440 pages

Publisher InTech

Published online 15, February, 2012

Published in print edition February, 2012

This book is a collective work of international experts in the neural stem cell field. The book incorporates the characterization of embryonic and adult neural stem cells in both invertebrates and vertebrates. It highlights the history and the most advanced discoveries in neural stem cells, and summarizes the mechanisms of neural stem cell development. In particular, this book provides strategies and discusses the challenges of utilizing neural stem cells for therapy of neurological disorders and brain and spinal cord injuries. It is suitable for general readers, students, doctors and researchers who are interested in understanding the principles of and new discoveries in neural stem cells and therapy.

\title{
How to reference
}

In order to correctly reference this scholarly work, feel free to copy and paste the following:

Chiara Rolando, Enrica Boda and Annalisa Buffo (2012). Immune System Modulation of Germinal and Parenchymal Neural Progenitor Cells in Physiological and Pathological Conditions, Neural Stem Cells and Therapy, Dr. Tao Sun (Ed.), ISBN: 978-953-307-958-5, InTech, Available from:

http://www.intechopen.com/books/neural-stem-cells-and-therapy/immune-system-modulation-of-germinal-andparenchymal-neural-progenitor-cells-in-physiological-and-pa

\section{INTECH}

open science | open minds

\section{InTech Europe}

University Campus STeP Ri Slavka Krautzeka 83/A 51000 Rijeka, Croatia Phone: +385 (51) 770447 Fax: +385 (51) 686166 www.intechopen.com

\section{InTech China}

Unit 405, Office Block, Hotel Equatorial Shanghai No.65, Yan An Road (West), Shanghai, 200040, China 中国上海市延安西路65号上海国际贵都大饭店办公楼 405 单元 Phone: +86-21-62489820

Fax: +86-21-62489821 
(C) 2012 The Author(s). Licensee IntechOpen. This is an open access article distributed under the terms of the Creative Commons Attribution 3.0 License, which permits unrestricted use, distribution, and reproduction in any medium, provided the original work is properly cited. 